IZA DP No. 7761

Deployments, Combat Exposure, and Crime

D. Mark Anderson

Daniel I. Rees

November 2013

Forschungsinstitut zur Zukunft der Arbeit Institute for the Study of Labor 


\title{
Deployments, Combat Exposure, and Crime
}

\author{
D. Mark Anderson \\ Montana State University \\ Daniel I. Rees \\ University of Colorado Denver \\ and IZA
}

\section{Discussion Paper No. 7761 \\ November 2013}

\author{
IZA \\ P.O. Box 7240 \\ 53072 Bonn \\ Germany \\ Phone: +49-228-3894-0 \\ Fax: +49-228-3894-180 \\ E-mail: iza@iza.org
}

Any opinions expressed here are those of the author(s) and not those of IZA. Research published in this series may include views on policy, but the institute itself takes no institutional policy positions. The IZA research network is committed to the IZA Guiding Principles of Research Integrity.

The Institute for the Study of Labor (IZA) in Bonn is a local and virtual international research center and a place of communication between science, politics and business. IZA is an independent nonprofit organization supported by Deutsche Post Foundation. The center is associated with the University of Bonn and offers a stimulating research environment through its international network, workshops and conferences, data service, project support, research visits and doctoral program. IZA engages in (i) original and internationally competitive research in all fields of labor economics, (ii) development of policy concepts, and (iii) dissemination of research results and concepts to the interested public.

IZA Discussion Papers often represent preliminary work and are circulated to encourage discussion. Citation of such a paper should account for its provisional character. A revised version may be available directly from the author. 
IZA Discussion Paper No. 7761

November 2013

\section{ABSTRACT}

\section{Deployments, Combat Exposure, and Crime}

During the period 2001-2009, four combat brigades and the 3rd Armored Cavalry Regiment were based at Fort Carson, Colorado. These units were repeatedly deployed during the Iraq War, allowing us to measure the effect of arguably exogenous changes in troop levels on violent crime in EI Paso County, where Fort Carson is located. Our results suggest that never-deployed units contributed to community violence in the form of assaults, murders, and robberies. In contrast, estimates of the relationship between the number of previously deployed units and violent crime are generally small and statistically insignificant. We conclude that soldiers returning from combat do not represent a special threat to public safety.

JEL Classification: K4, H56

Keywords: combat, crime, Iraq War, violence

Corresponding author:

D. Mark Anderson

Department of Agricultural Economics and Economics

Montana State University,

P.O. Box 172920

Bozeman, MT 59717-2920

USA

E-mail: dwight.anderson@montana.edu 
I'm happier. I know I'm alive and I'm home. There's no reason to be mad.

-- Army National Guard Specialist Michael Gillis

I get mad a lot...I feel like fighting. Even if someone looks like he could beat me up, I don't care. -- Marine Corporal Jose Rosales

\section{INTRODUCTION}

Although flagged for symptoms of mental illness by the U.S. Army, Specialist Robert H. Marko was deployed to Iraq in February 2007, where he served with the $2^{\text {nd }}$ Brigade of the $2^{\text {nd }}$ Infantry Division. He returned to Fort Carson, Colorado almost a year later convinced that he was transforming into "a true Black Raptor," able to kill "without mercy or reason.” On October 13, 2008, he admitted to raping and murdering Judilianna Lawrence, a local 19-year-old woman he had met online. ${ }^{1}$

The tragic killing of Ms. Lawrence was not an isolated incident. In the space of four years (2005-2008), 10 soldiers from Fort Carson were charged by civilian authorities in connection with 9 murders and an $11^{\text {th }}$ soldier from Fort Carson committed suicide after killing his wife (Henley and Roeder 2005; Olinger 2008; Philipps 2009; Riley and Roeder 2009). ${ }^{2}$ The majority of these soldiers had been exposed to intense conflict while serving in Iraq, leading the media and prominent policymakers such as U.S. Senator Kenneth Salazar to question whether

\footnotetext{
${ }^{1}$ Our description of Specialist Marko's history and the murder of Judilianna Lawrence is based on reporting by Benzel (2008), Frosch and Alvarez (2008), and Mitchell (2008a).

${ }^{2}$ A $12^{\text {th }}$ Fort Carson soldier, Private Timothy Parker, was convicted of involuntary manslaughter by a military court for beating Specialist Piotr Szczypka to death on November 11, 2005 (Huspeni 2006; Riley and Roeder 2009). Private Parker belonged to the $3^{\text {rd }}$ Brigade of the $4^{\text {th }}$ Infantry Division, based at Fort Carson.
} 
the units deployed from Fort Carson had been pushed too far (Mitchell 2008b; Luning 2009; Alvarez and Frosch 2009a; Philipps 2009; Riley and Roeder 2009; Smith 2009). ${ }^{3}$

In theory, combat exposure could have either a positive or negative effect on postdeployment violence. Exposure to combat is often described by mental health experts as the trigger for, or indirectly leading to, acts of violence committed upon returning home (Grossman et al. 2008; Killgore et al. 2008; Songtag and Alvarez 2008; Elbogen et al. 2012a; MacManus et al. 2012; MacManus et al. 2013; Sreenivasan et al. 2013), but previous studies have found that exposure to adversity, including combat, can result in "post-traumatic growth” (Elder and Clipp 1989; Fontana and Rosenheck 1998; Koenig et al. 1998; McMillen and Cook 2003; Dohrenwend et al. 2004; Maguen et al. 2006; Forstmeier et al. 2009). Several features of post-traumatic growth (e.g., increased compassion, self-discipline, resilience, and spirituality) could reduce the propensity to engage in violent behavior. ${ }^{4}$

A substantial proportion of American soldiers who saw combat in Iraq developed posttraumatic stress disorder (PTSD) and/or exhibited the symptoms of depression upon returning home (Hoge et al. 2004; Hoge et al. 2006; Milliken et al. 2007; Smith et al. 2008; Sciolli et al. 2010). Although PTSD and depression are associated with domestic violence (Maiuro et al.

\footnotetext{
${ }^{3}$ While the Fort Carson murders received more attention from the media and policymakers, soldiers from Forts Bragg, Campbell, Drum, and Riley were also charged in connection with high profile violent crimes after returning from Iraq and Afghanistan (Main 2005; Milburn 2005; Collins 2009; Lowary 2010; Tang 2010; Kristof 2012).

${ }^{4}$ Park, Cohen and Murch (1996), Tedeschi and Calhoun (1996), and Linley and Joseph (2004) review the concept of post-traumatic growth (also known as "stress-related growth"). According to Linley and Joseph (2004, p. 11):

Positive changes following adversity have long been recognized in philosophy, literature, and religion...They have been reported empirically following chronic illness, heart attacks, breast cancer, bone marrow transplants, HIV and AIDS, rape and sexual assault, military combat, maritime disasters, plane crashes, tornadoes, shootings, bereavement, injury, recovery from substance addiction, and in the parents of children with disabilities...It is through this process of struggling with adversity that changes may arise that propel the individual to a higher level of functioning than that which existed prior to the event. These positive changes have been labeled posttraumatic growth, stress-related growth....and positive adaptation.
} 
1988; Byrne and Riggs 1996; Chaffin et al. 1996; Begic and Jokic-Begic 2001; Dobie et al. 2004; Galovskia and Lyons 2004), anger issues (Fava 1998; Jakupcak et al. 2007), substance use (McFall et al. 1992; Swendsen and Merikangas 2000; Dobie et al. 2004; Mills et al. 2006) and arrest (Eyestone and Howell 1994; Fazel and Danesh 2002; Elbogen et al. 2012b), they can lead to withdrawal from social activities (Ferster 1973; Mason et al. 2001; Galovskia and Lyons 2004; Schnurr et al. 2009; Sharpley and Bitsika 2010; Chu 2011), potentially limiting the opportunities to engage in violent behavior. PTSD has also been linked to emotional numbing (Riggs et al. 1998; Feeny et al. 2000; Mason et al. 2001; Galovskia and Lyons 2004; Samper et al. 2004), while depression can cause fatigue and lower levels of energy (Nestler et al. 2002; Nutt et al. 2007). Criminologists have argued that individuals suffering from depression may lack the requisite drive to engage in violent behavior (Agnew 1992; Mazerolle and Piquero 1997; Broidy 2001).

Drawing on incident-level files provided by Colorado Front Range police agencies for the period 2001-2009, the current study examines the relationship between combat exposure and post-deployment violence. During this period, well over 100 U.S. soldiers, many of whom were stationed at Fort Carson, were charged with murder after returning from Iraq or Afghanistan (Songtag and Alvarez 2008; Riley and Roeder 2009). Our empirical strategy is based on the premise that troop movements into and out of Fort Carson were exogenous, driven by events in Iraq and the recommendations of the 2005 Base Realignment and Closure (BRAC) Commission.

We find strong evidence that never-deployed combat units represent a threat to public safety. Specifically, increases in the number of never-deployed combat brigades at Fort Carson are associated with more reports of assault, murder, and robbery in El Paso County, where Fort Carson is located. They are also associated with more arrests of 18- through 29-year old males 
for violent crimes. In contrast, estimates of the relationship between previously deployed combat brigades and violent crime are generally small and statistically insignificant at conventional levels. The hypothesis that previously deployed combat brigades had a larger effect on violent crime than never-deployed brigades is consistently rejected.

\section{BACKGROUND}

Fort Carson is located just a few miles south of Colorado Springs, a medium-sized city in El Paso County, Colorado that was experiencing rapid population growth during the 2000s. ${ }^{5}$ When the spate of murders involving Fort Carson soldiers occurred, residents of Colorado Springs were described as "shaken” and "outraged” (Frosch 2008; Smith 2009). U.S. Senator Kenneth Salazar asked for a review of the soldiers' records (Mitchell 2008b), and the Army responded by conducting a three-month-long investigation focused on the $2^{\text {nd }}$ Brigade of the $2^{\text {nd }}$ Infantry Division. Nine of the Fort Carson soldiers connected to the murders belonged to the $2^{\text {nd }}$ Brigade, which experienced heavy causalities during its two deployments to Iraq.

This investigation, the results of which were released in July 2009, found an association between combat exposure and violence. Noting that such an association was "consistent with recent research on combat exposure” (U.S. Army Medical Command 2009, p. ES-3), the investigation concluded that the "combination of multiple pre-existing personal risk factors in given individuals, combat intensity/exposure, and other unmeasured unit factors may have increased the risk of violent behavior...” (U.S. Army Medical Command 2009, p. ES-3). ${ }^{6}$

\footnotetext{
${ }^{5}$ Colorado Springs had a population of 360,890 according to the 2000 U.S. Census; its population had reached 416,427 by 2010. El Paso County had a population of 519,463 according to the 2000 U.S. Census; its population had reached 627,159 by 2010 .

${ }^{6}$ The U.S. Army Medical Command (2009) reached this conclusion by comparing the personnel records of soldiers from the $2^{\text {nd }}$ Brigade of the $2^{\text {nd }}$ Infantry Division with those of soldiers from the $3^{\text {rd }}$ Brigade of the $4^{\text {th }}$ Infantry Division, also based at Fort Carson. Soldiers from the $2^{\text {nd }}$ Brigade were more likely to have been diagnosed with an
} 
A few months after these results were released, the Army-wide Comprehensive Soldier Fitness program (CSF) was launched (Hames 2009; Millerrodgers 2010; Horgan 2011). The goal of the CFS is to help soldiers cope with the stresses involved with military service by fostering resilience and "providing Soldiers skills needed to take care of themselves, their families, and their peers” (Lester et al. 2011, p. 24). Fort Carson responded to the murders and subsequent investigation by developing the Embedded Behavioral Health (EBH) program (Fisher 2009; Carabajal 2011). ${ }^{7}$ Under this program, EBH teams composed of one psychiatrist (or psychiatric nurse practitioner), psychologists, and social workers were tasked with providing counseling to troops deployed overseas and evaluating the mental health of returning soldiers (Carabajal 2011; Collins 2012; Sheehy 2012; Cho-Stutler 2013). Since their debut at Fort Carson in 2009, EBH teams have been established at Forts Bliss, Campbell, Drum, Hood, and Knox (Ingram 2009; Carabajal 2011; Rose 2102; Block 2013; Grey 2013; Kocherga 2013). The Army is requiring that all combat brigades incorporate EBH teams by 2016 (Collins 2012; Holley 2013).

anxiety disorder such as PTSD and were more likely to have tested positive for an illegal drug than were soldiers from the $3^{\text {rd }}$ Brigade (pp. 11-12). Citing previous research (Elbogen and Johnson 2009), the U.S. Army Medical Command went on to note that both substance use and anxiety disorders are risk factors for aggressive behavior (p. 17).

${ }^{7}$ Fort Carson also established the Courtesy Patrol program, under which military officers patrol the streets of downtown Colorado Springs on Friday and Saturday nights encouraging off-duty soldiers to act responsibly (Cantrell 2011; Ingram 2012). Civilian authorities responded to the series of murders involving Fort Carson soldiers by establishing the El Paso County Veteran Trauma Court, a jail-diversion program for veterans with trauma-related disorders or substance abuse problems (Warner 2010; Benzel 2011; Werthmann 2012). 


\subsection{Fort Carson troop movements 2001-2009}

At the outset of the Iraq War, Fort Carson was home to the $3^{\text {rd }}$ Armored Cavalry Regiment (3ARC) and the $3^{\text {rd }}$ Brigade of the $4^{\text {th }}$ Infantry Division (3BCT-4ID). ${ }^{8}$ These were among the first Army units to be deployed to Iraq, and both conducted combat operations through the remainder of 2003 and into 2004 (Ricks 2006; Defense Department 2007; Roeder 2013).

The 3ARC was deployed to Iraq once more before being permanently relocated to Fort Hood based on the recommendations of the 2005 BRAC Commission. ${ }^{9}$ When the 3ARC was relocated to Fort Hood, its aviation element stayed at Fort Carson, reflagged as the $1^{\text {st }}$ Squadron, $6^{\text {th }}$ Cavalry (1-6 CAV). ${ }^{10}$ The 3BCT-4ID was deployed two more times during the period under study. Its third deployment was unexpectedly extended to 15 months after President Bush announced the so-called "surge” in U.S. troops (Brook and Michaels 2007; Tyson and White 2007).

Based on the recommendations of the 2005 BRAC Commission, three additional combat brigades were reassigned to Fort Carson during the period under study (Robson 2004; Slevin

\footnotetext{
${ }^{8}$ In addition to the 3ARC and the 3BCT-4ID, the $10^{\text {th }}$ Special Forces Group (Airborne) was stationed at Fort Carson when the Iraq War began. Composed of approximately 1,000 soldiers, its repeated deployments to Iraq and Afghanistan were kept secret (Roeder 2004). The $3^{\text {rd }}$ Battalion of the $10^{\text {th }}$ Special Forces Group (Airborne), composed of approximately 400 soldiers, was activated at Fort Carson on August 19, 2010. Non-combat units stationed at Fort Carson at the outset of the Iraq War included the $4{ }^{\text {th }}$ Engineer Battalion, the $43^{\text {rd }}$ Area Support Group, the $10^{\text {th }}$ Combat Support Hospital, the $759^{\text {th }}$ Military Police Battalion, and the Headquarters Company of the $7^{\text {th }}$ Infantry Division. The $71^{\text {st }}$ Ordnance Group was activated at Fort Carson on October 16, 2005.

${ }^{9}$ The 2005 BRAC Commission recommended closing 22 major U.S. military bases and “realigning” 33 other military bases (Gonzales 2009). The commission's recommendations went into effect on November 9, 2005 after Congress failed to pass a joint resolution of disapproval (Miles 2005).

${ }^{10}$ Composed of approximately 380 soldiers, the 1-6 CAV was deployed to Iraq in August 2007. It was permanently relocated from Fort Carson to Fort Riley in June 2009, replaced by the $1^{\text {st }}$ Battalion, $2^{\text {nd }}$ Aviation Regiment, $2^{\text {nd }}$ Infantry Division (1-2 AVN). The 1-2 AVN arrived at Fort Caron from Camp Eagle, South Korea in April 2009.
} 
2005; Lorge 2007). ${ }^{11}$ The $2^{\text {nd }}$ Brigade of the $2^{\text {nd }}$ Infantry Division (2BCT-2ID) arrived in July 2005 after spending one year in Iraq; the $2^{\text {nd }}$ Brigade of the $4^{\text {th }}$ Infantry Division (2BCT-4ID) arrived from Fort Hood in June 2007; and the $1^{\text {st }}$ Brigade of the $4^{\text {th }}$ Infantry Division (1BCT4ID) arrived from Fort Hood in July 2009. The 2BCT-2ID was deployed to Iraq in October 2006, reflagged as the $4^{\text {th }}$ Brigade of the $4^{\text {th }}$ Infantry Division in April 2008, and deployed to Afghanistan in May 2009. The 2BCT-4ID was deployed to Iraq in August 2008.

\section{PREVIOUS STUDIES}

No previous study has examined whether troop movements such as those described above are related to the number of crimes reported to local law enforcement authorities. Medical researchers have documented an association between being exposed to combat in Iraq or Afghanistan and post-deployment violence (MacManus et al. 2012, MacManus et al. 2013). However, these researchers determined combat exposure based on military occupation (e.g., whether a soldier was assigned to an infantry or logistics unit), which is likely to be correlated with factors such as personality and test scores (Zeidner et al. 2001; Ball and Peake 2006; MacLean and Parsons 2010). ${ }^{12}$

Economists have adopted more credible identification strategies based on draft lottery outcomes (Rohlfs 2010; Galiani et al. 2011; Albæk et al. 2013; Siminski et al. 2013; Lindo and Stoecker forthcoming). Their focus, however, has been on the relationship between military

\footnotetext{
${ }^{11}$ Appendix B provides more information about the combat units stationed at Fort Carson during the period 20012009, including deployment dates. Deployment dates were gathered from a wide variety of sources including the following: Army News, Colorado Springs Gazette, Denver Post, Fort Carson Mountaineer, Killeen Daily Herald, and Laredo Morning Times.

${ }^{12}$ Other studies in the medical literature that have documented a positive, but potentially spurious, association between combat exposure and violent behavior include Elbogen et al. (2012a, 2013).
} 
service and crimes committed after discharge. ${ }^{13}$ Moreover, their results have been mixed. For instance, Galiani et al. (2011) found that service in the Argentine military increased the likelihood of being prosecuted or convicted of committing a property crime, but had no impact on the likelihood of being prosecuted or convicted of committing a violent crime; Lindo and Stoecker (forthcoming) found that service in the U.S. military during the Vietnam War decreased the likelihood of incarceration for nonviolent crime, but increased the likelihood of incarceration for violent crime. ${ }^{14}$

In addition to exploiting a unique natural experiment, the current study differs from the previous work by economists on military service and crime in at least three important respects. First, we are able to assess the immediate impact of troops returning home from combat. Rather than relying on arrest or incarceration records from years or even decades after service, we observe monthly crime and arrest data before, during, and after overseas deployments.

Second, previous studies by economists have typically estimated the effects of military service per se, but the number of people who serve in the military greatly exceeds the number who actually see combat (Siminski et al. 2013). In contrast, our focus is on combat units that saw action in Iraq during the period under study. Using unit-specific information on fatalities suffered in Iraq, we are able to explore the relationship between combat intensity and post-

\footnotetext{
${ }^{13}$ Economists have also used the Vietnam-era draft lottery to study the effects of military service on earnings (Angrist 1990; Angrist and Chen 2007), disability status (Angrist and Chen 2007), health and mortality (Angrist and Chen 2007; Dobkin and Shabani 2009; Conley and Heerwig 2012), and household stability (Conley and Heerwig 2011).

${ }^{14}$ Using draft lottery outcomes as an instrument, Siminski et al. (2013) examined a sample of Australian men between 41 and 65 years of age. These authors found no evidence that military service was related to violent crime. Using a similar empirical approach, Albæk et al. (2013) found that peacetime service in the Danish military had no impact on the likelihood of being arrested for a violent crime. Rohlfs (2010) analyzed data from the National Vietnam Veterans Readjustment Study. He found evidence that self-reported exposure to combat in Vietnam was associated with more violent crime among blacks. Among whites, estimates of the relationship between combat exposure and violent crime were positive but not statistically significant.
} 
deployment violence. To our knowledge, no previous study has used unit-specific information on fatalities to examine the effect of combat intensity on crime.

Lastly, our results are likely to be more relevant to current policy formation than results based on data pertaining to Vietnam War veterans. Perhaps the most obvious difference between soldiers who served in Iraq and those who served in Vietnam is that the former were volunteers whereas a substantial portion of the latter were draftees. While tour lengths for the U.S. Army were roughly similar during the Iraq War and the Vietnam War, the vast majority of troops in Vietnam served single, year-long deployments. Repeated deployments were much more common among American troops during the Iraq War and many soldiers spent three to four cumulative years at war (Zoroya 2010). In addition, U.S. soldiers faced radically different threats and combat environments during the two wars. ${ }^{15}$

\section{THE DATA AND EMPIRICAL MODEL}

Information on crimes reported to Colorado Front Range police agencies were obtained from incident-level files compiled by the National Incident Based Reporting System (NIBRS) and made available by the Interuniversity Consortium for Political and Social Research (ICPSR). These data include information on the type of offense, where the crime took place, and when it occurred. One advantage to using the incident-level files is that they include information on all offenses reported as opposed to only those that ended in an arrest. Because we are interested in

\footnotetext{
${ }^{15}$ In Vietnam, U.S. forces faced a well-defined threat in the Vietcong and North Vietnamese Army, while U.S. forces in Iraq faced an unorganized, “mixed-bag” insurgency (Akers 2011, p. 2). Carpenter (2007, p. 21) described the conflict in Iraq as resembling a "...Hobbesian struggle of all against all rather than the kind of conventional insurgency the United States encountered in Vietnam.” While the loss of life was greater in Vietnam, the enemy in Iraq has been described as crueler, with a penchant for execution rather than taking prisoners (Komarow 2005).
} 
relatively rare events such as murder and rape, the distinction between reported crimes and arrests is potentially important.

Twenty-one Colorado Front Range police agencies provided data to NIBRS during the period 2001-2009. ${ }^{16}$ Several of these agencies (including the Arapahoe County Sheriff's Office, the Aurora Police Department, the Colorado Springs Police Department, the El Paso County Sheriff's Office, and the Jefferson County Sheriff's Office) had jurisdiction over communities with more than 100,000 residents. Unfortunately, the Denver Police Department did not provide data to NIBRS during the period under study.

The Colorado Springs Police Department and the El Paso County Sheriff's Office routinely interact with, and arrest, soldiers from Fort Carson (Huspeni and Roeder 2007; Ridder 2007; Olinger 2008; Philipps 2009; Warner 2010). The other 19 Colorado Front Range police agencies that provided data to NIBRS during the period under study are located outside of El Paso County and are considered untreated. That is, we assume that troop movements into and out of Fort Carson had no effect on crime in the communities over which these 19 agencies had jurisdiction. $^{17}$

\footnotetext{
${ }^{16}$ The Colorado Front Range urban corridor extends north from Pueblo to Fort Collins along Interstate Highway 25. It includes the Denver-Aurora-Lakewood Metropolitan Statistical Area (MSA), the Colorado Springs MSA, the Boulder MSA, and the Greeley, MSA. The agencies that contributed data to our analysis are: the Adams County Sherriff's Office, the Arapahoe County Sherriff's Office, the Aurora Police Department, the Berthoud Police Department, the Broomfield Police Department, the Centennial Police Department, the Colorado Springs Police Department, the Commerce City Police Department, the Eaton Police Department, the El Paso County Sherriff's Office, the Erie Police Department, the Glendale Police Department, the Golden Police Department, the Greenwood Village Police Department, the Jefferson County Sherriff's Office, the Lakewood Police Department, the Larimer County Sherriff's Office, the Northglenn Police Department, the Parker Police Department, the Sheridan Police Department, and the Wheat Ridge Police Department.

${ }^{17}$ The portion of Fort Carson located within El Paso County forms a census-designated place with a 2010 population of 13,339. Covering an area of more than 500 square miles, Fort Carson extends into unincorporated Pueblo County and unincorporated Fremont County. The population living on base is not under the jurisdiction of the Colorado Springs Police Department or the El Paso County Sheriff's Office. The resort town of Manitou Springs, located in El Paso County, is only 13 miles from Fort Carson. Grouping crime reports from the Manitou Springs Police Department with those from the Colorado Springs Police Department and the El Paso County Sheriff's Office did not have an appreciable impact on the estimates presented below. Although Fountain Colorado is located in El Paso
} 
We begin the empirical analysis by estimating a Poisson regression in which crime in El Paso County is related to troop movements into and out of Fort Carson by the following equation:

$$
\ln \lambda_{j t}=\alpha_{0}+\alpha_{1} \text { Brigades }_{j t}+\boldsymbol{\beta}^{\prime} \boldsymbol{X}_{j t}+v_{j}+\varepsilon_{j t}
$$

where $\lambda_{j t}$ represents the expected number of offenses in agency $j$ and month $t{ }^{18}$ The independent variable of interest is Brigades $j$, equal to 0 for the 19 untreated police agencies. For the treated agencies (the Colorado Springs Police Department and the El Paso County Sheriff's Office), Brigades ${ }_{j t}$ is equal to the number of combat brigades based at Fort Carson but not deployed overseas in month $t$. The vector of controls, $\boldsymbol{X}_{j t}$, includes 8 year indicators, 11 month indicators, the county unemployment rate, and the natural log of the population over which agency $j$ had jurisdiction ${ }^{19}$; the inclusion of agency fixed effects, $v_{j}$, ensures that our estimates of $\alpha_{1}$ are identified using within-agency variation. Although not shown, equation (1) can be augmented with agency-specific linear time trends to account for smoothly evolving crime trends at the community level.

Figure 1 shows the number of combat brigades at Fort Carson over the period 2001-2009. The largest changes in troop levels correspond to the 13-month deployments of the 3ARC and

\footnotetext{
County, crime reports from the Fountain Police Department were not used in the analysis because they were only available for a limited number of years.

${ }^{18}$ See Cameron and Trivedi (1986) and Grootendorst (2002) for descriptions of the Poisson regression model. As noted by Card and Dahl (2011), an advantage of the Poisson regression model is that including fixed effects does not lead to an incidental parameters problem. Appendix Table A1 provides descriptive statistics for the variables used in the analysis.

${ }^{19}$ There is evidence that economic conditions and time of year are important predictors of crime (Raphael and Winter-Ebmer 2001; Gould et al. 2002; Jacob et al. 2007; McDowall et al. 2012).
} 
the 3BCT-4ID when the Iraq War began. The 3BCT-4ID was composed of approximately 3,500 soldiers, the standard size of a U.S. Army combat brigade (Slevin 2005; Foster 2006; Benzel 2010). Because the 3ARC was composed of approximately 5,200 soldiers (Finely 2005; Roeder 2013), its 2003 deployment corresponds to a 1.5-brigade decrease and its return to Fort Carson in April 2004 corresponds to a 1.5-brigade increase.

After April 2004, the number of combat brigades at Fort Carson did not fall below unity. Nevertheless, there was still considerable variation in troop levels resulting from overseas deployments and the re-stationing of brigades according to the recommendations of the 2005 BRAC Commission. This variation can be thought of as exogenous. As noted by previous researchers, operational needs and world events determine where U.S. Army units are stationed and when they are deployed (Lyle 2006; Engel et al. 2010; Cesur et al. 2013). ${ }^{20}$

In an effort to explore the relationship between overseas deployments and crime, we estimate:

$$
\begin{aligned}
& \ln \lambda_{j t}=\alpha_{0}+\alpha_{1}\left(\text { Never-Deployed Brigades } s_{j t}\right)+\alpha_{2}\left(\text { Once-Deployed Brigades }_{j t}\right)+ \\
& \alpha_{3}(\text { Twice-Deployed Brigades } j \text {-D })+\boldsymbol{\beta} \boldsymbol{X}_{j t}+v_{j}+\Theta_{j} \cdot t+\varepsilon_{j t},
\end{aligned}
$$

\footnotetext{
${ }^{20}$ Although its primary goals were to produce cost savings through reducing excess infrastructure and to foster "jointness", economic impact on local communities was also considered by the 2005 BRAC Commission (U.S. Government Accountability Office 2009, pp. 7-8). As a test of whether economic conditions in El Paso County influenced the number of combat brigades assigned to Fort Carson but not deployed in month $t$, we estimated the following equation using ordinary least squares:

$$
\text { Brigades }_{j t}=\pi_{0}+\sum_{k=1}^{K} \pi_{k} \text { Unemployment }_{j t-k}+\beta^{\prime} \mathbf{X}_{j t}+v_{j}+u_{j t} \text {. }
$$

The results of this exercise are reported in Appendix Table A2. The estimated coefficients of lagged unemployment are neither jointly nor individually statistically significant at conventional levels.
} 
where, for the treated agencies, Never-Deployed Brigades $_{j t}$ is equal to the number of combat brigades at Fort Carson that had not been deployed to Iraq prior to month $t$; Once-Deployed Brigades $_{j t}$ is equal to the number of brigades at Fort Carson that had been deployed to Iraq once prior to month $t$; and Twice-Deployed Brigades $j$ is equal to the number of brigades at Fort Carson that had been deployed two or more times. ${ }^{21}$ For the 19 untreated police agencies, the variables Never-Deployed Brigades $j t$, Once-Deployed Brigades $s_{j t}$, and Twice-Deployed Brigades $s_{t}$ are equal to 0 in every month, $t$. Agency-specific linear time trends are represented by $\Theta_{j} \cdot t$.

The specification described in the preceding paragraph allows us to test whether previously deployed brigades had the same effect on crime in El Paso County as did neverdeployed brigades. Although exposure to combat is often described as the trigger for acts of violence committed upon returning home (Killgore et al. 2008; Songtag and Alvarez 2008; Elbogen et al. 2012a; Sreenivasan et al. 2013), there is also evidence that it can result in increased compassion, self-discipline, resilience, and spirituality (Elder and Clipp 1989; Fontana and Rosenheck 1998; Dohrenwend et al. 2004; Maguen et al. 2006; Forstmeier et al. 2009), all of which could potentially reduce the propensity to engage in violent behavior.

To explore the effects of combat intensity, we use data from the Iraq Coalition Casualty Count on the number of fatalities experienced by Fort Carson units while deployed. These data include information on the fallen soldier's military branch, unit, and date of death. Construction of the fatality counts required matching fatality reports with Fort Carson combat units (i.e., the 3ARC, the 1BCT-4ID, the 2BCT-2ID, the 2BCT-4ID, and the 3BCT-4ID). ${ }^{22}$ The median

\footnotetext{
${ }^{21}$ Appendix Figure A1 shows numbers of never-deployed, once-deployed and twice-deployed combat brigades at Fort Carson during the period 2001-2009.

${ }^{22}$ For example, Sgt. Denis Gallardo, who died on November 22, 2005, was assigned to Troop E, $2^{\text {nd }}$ Squadron. Troop E, $2^{\text {nd }}$ Squadron belonged to the 3ARC. To take another example, Corp. Jason Pautsch, who died on April 10, 2009, was assigned to Company A, $1^{\text {st }}$ Battalion, $67^{\text {th }}$ Armor Regiment. Company A, $1^{\text {st }}$ Battalion, $67^{\text {th }}$ Armor Regiment belonged to the 2BCT-4ID. These data are available at http://icasualties.org/Iraq/Index.aspx.
} 
number of casualties experienced by Fort Carson combat units during the period under study was

64. ${ }^{23}$ Using 64 fatalities as a benchmark, we estimate:

$$
\begin{aligned}
& \left.\ln \lambda_{j t}=\alpha_{0}+\alpha_{1}(\text { Never-Deployed Brigades } j t)+\alpha_{2}(\text { Brigades 0-64 Fatalities } j t)\right)+ \\
& \alpha_{3}\left(\text { Brigades } \geq 65 \text { Fatalities }_{j t}\right)+\boldsymbol{\beta}^{\prime} \boldsymbol{X}_{j t}+v_{j}+\Theta s \cdot t+\varepsilon_{j t},
\end{aligned}
$$

where, for the treated agencies, Brigades 0-64 Fatalities $j$ is defined as the number of previously deployed combat brigades at Fort Carson that had experienced between 0 and 64 fatalities prior to month $t$ and Brigades $\geq 65$ Fatalities $_{j t}$ is defined as the number of combat brigades at Fort Carson that had experienced 65 or more fatalities prior to month $t .^{24}$ For the untreated police agencies, the variables Brigades 0-64 Fatalities $_{j t}$ and Brigades $\geq 65$ Fatalities $_{j t}$ are equal to 0 in every month, $t$.

\section{THE RESULTS}

\subsection{Troop levels and crime in El Paso County}

Figure 2a plots the natural log of violent crimes reported to the El Paso County Sheriff's Office against the number of combat brigades stationed at Fort Carson but not deployed overseas; Figure 2b plots the natural log of violent crimes reported to the Colorado Springs Police Department against the number of combat brigades stationed at Fort Carson but not deployed overseas. The solid lines are from two separate ordinary least squares (OLS)

\footnotetext{
${ }^{23}$ Before the 3ARC was permanently relocated to Fort Hood, a total of 64 soldiers from this unit were killed in Iraq. During the period 2001-2009, a total of 72 soldiers from the 1BCT-4ID were killed in Iraq; a total of 97 soldiers from the 2BCT-2ID were killed in Iraq; a total of 58 soldiers from the 2BCT-4ID were killed in Iraq; and a total of 35 soldiers from the 3BCT-4ID were killed in Iraq. The 1-6 CAV was deployed to Iraq from August 2007 through November 2008. It suffered no fatalities during this deployment (Emert 2009). The 1-2 AVN was not deployed to Iraq during the period under study.

${ }^{24}$ Appendix Figure A2 shows the variation over time in Brigades 0-64 Fatalities $j$ and Brigades $\geq 65$ Fatalities $_{j t}$.
} 
regressions of violent crimes on Brigades $j$. An additional combat brigade at Fort Carson is associated with a 6.3 percent increase in violent crimes reported to the El Paso County Sheriff's Office $\left(\mathrm{e}^{.0613}-1=.063\right)$ and a 2.5 percent increase in violent crimes reported to the Colorado Springs Police Department.

Figures $2 \mathrm{a}$ and $2 \mathrm{~b}$ provide descriptive evidence consistent with the hypothesis that Fort Carson soldiers directly contributed to community violence, but there are at least two alternative explanations that merit exploration. First, it is possible that economic activity mediates the relationship between troop levels and violent crime. Soldiers clearly contribute to local economic activity (Hooker and Knetter 2001; Poppert and Herzog 2003) and their extended overseas deployments could have forced civilian residents of El Paso County to turn to illicit sources of income (e.g., theft or robbery). Second, it is possible that the number of combat brigades stationed at Fort Carson tracked secular crime trends. By estimating equation (1), which includes the county unemployment rate as well as year fixed effects on the right-hand side, we can rule out these alternative explanations.

Table 1 presents Poisson estimates of equation (1). Standard errors are corrected for clustering at the county-year level. ${ }^{25}$ Although not shown, controls for the county unemployment rate and agency population are included.

The baseline specification suggests that a one-brigade increase in troop levels at Fort Carson is associated with a 2.4 percent increase in violent crime. Adding agency-specific linear time trends does not have an appreciable impact on this estimate, although it does become more

\footnotetext{
${ }^{25}$ As noted below, correcting for clustering at the agency level produced similar results to those reported. We also experimented with clustering the standard errors at the county level. Because one regressor (unemployment) varied at the county level and 9 Colorado Front Range counties contributed data to the analysis, we used critical values from a $\mathrm{t}_{\mathrm{G}-\mathrm{K}-1}$ distribution, where $\mathrm{G}$ is 9 and $\mathrm{K}$ is 1 (Cohen and Dupas 2010). Again, the results were similar to those reported.
} 
precise. There is no evidence of a relationship between the number of combat brigades at Fort Carson and property crimes reported to the Colorado Springs Police Department and the El Paso County Sheriff's Office.

When violent crimes are decomposed, we find that an additional combat brigade is associated with a 5 percent increase in robberies and a 3.7 percent increase in aggravated assaults. ${ }^{26}$ These estimates suggest that the typical Fort Carson soldier was more prone to violence than the residents of communities over which the El Paso County Sheriff's Office and the Colorado Springs Police Department had jurisdiction. As noted above, a standard U.S. Army combat brigade consists of approximately 3,500 soldiers, or slightly more than 0.5 percent of the combined population of the treated agencies, while a one-brigade increase in troop levels is associated with a 2.4 percent increase in the total number of violent crimes and even larger increases in robberies and aggravated assaults.

As a test of whether troop movements into and out of Fort Carson can be thought of as exogenous, we experimented with adding leads of Brigades $_{j t}$ to the right-hand side of the estimating equation. The results of this exercise are reported in Table 2. Adding leads of one to 12 months has very little impact on the estimated relationship between troop levels and violent crime. Moreover, these leads are never significant at conventional levels.

Table 3 presents results from a series of robustness checks. In the first column, we estimate equation (1) using OLS. Because the dependent variable in this specification is $\ln \left(\right.$ Violent Crimes $_{j t}$ ), agency-months with no reported offenses were excluded from the

\footnotetext{
${ }^{26}$ The estimated relationship between Brigades $_{j t}$ and reported rapes, although positive, is not statistically significant at conventional levels. Likewise, the estimated relationship between Brigades $s_{j t}$ and simple assaults (defined as a weaponless assault in which the victim did not suffer severe bodily harm) is positive but not statistically significant. The estimated relationship between murder and Brigades $_{j t}$ is from an OLS regression. An additional brigade is associated with a reduction in the probability that a murder occurred in month $t$ and agency $j$ of 0.0018 . However, this estimate is not statistically significant at conventional levels.
} 
regression. The OLS estimate is a little larger than the baseline Poisson estimates presented in

Table 1: a one-brigade increase in troop levels is associated with a 3.2 percent increase in violent crime.

Next, we assume that $\exp \left(\varepsilon_{j t}\right)$ follows a gamma distribution with mean of 1 and variance . In other words, we estimate a negative binomial regression model. ${ }^{27}$ The estimated relationship between Brigades $_{j t}$ and violent crime obtained using this approach is similar to the baseline estimates presented in Table 1.

Up to this point in the analysis, we have assumed that both the Colorado Springs Police Department and the El Paso County Sheriff's Office were, in effect, treated. Excluding observations from the El Paso County Sheriff's Office from the analysis results in a smaller estimate of $\alpha_{1}$ : a one-brigade increase in troop levels at Fort Carson is associated with a 2.1 percent increase in violent crime. When the Colorado Springs Police Department observations are excluded, an additional brigade is associated with a 6.2 percent increase in violent crime. These estimates are similar to the naïve bivariate estimates presented in Figures 2a and 2b, suggesting that we have identified a valid natural experiment.

The remaining columns of Table 3 report estimates of $\alpha_{1}$ restricting the analysis to agencies with jurisdiction over communities with more than 50,000 residents, replacing the year and month fixed effects with month-year fixed effects, and correcting for clustering at the agency (as opposed to the county-year) level. ${ }^{28}$ These estimates are consistently positive, significant at conventional levels, and roughly equal in magnitude to the baseline estimates in Table 1.

\footnotetext{
${ }^{27}$ If $\sigma$ is assumed to equal 0 , then the negative binomial reduces to the Poisson model.

${ }^{28}$ Nine of the 21 agencies had populations over the 50,000 cutoff. Our results were also robust to restricting the analysis to agencies with jurisdiction over populations with more than 100,000 residents and including agency-bymonth fixed effects. For the sake of brevity, these are not reported in Table 3 but are available from the authors upon request.
} 


\subsection{Combat Exposure and Violent Crime}

Table 4 reports estimates of equation (2). They suggest that never-deployed combat units contributed to community violence in the form of assaults, murders, and robberies. For instance, an additional never-deployed brigade at Fort Carson is associated with a 0.118 increase in the probability that a murder occurred in agency $j$ and month $t$. An additional never-deployed brigade is also associated with a 9.1 percent increase in robberies, a 7.7 percent increase in aggravated assaults, and a 3.1 percent increase in simple assaults.

Estimates of the relationship between previously deployed combat units at Fort Carson and violent crime are generally small and statistically insignificant. The hypothesis that oncedeployed brigades had a larger effect on violent crime than never-deployed brigades is consistently rejected at conventional levels. The hypothesis that twice-deployed brigades had a larger effect on violent crime than never-deployed brigades can be rejected except when the outcome is rape or robbery. Although an additional twice-deployed brigade is associated with a 7.4 percent increase in robberies, this estimate is statistically indistinguishable from the estimated relationship between never-deployed brigades and robberies. Likewise, we cannot reject the hypothesis that twice-deployed brigades had the same effect on reports of rape as did never-deployed brigades.

Table 5 reports estimates of equation (3). They provide little evidence that exposure to combat, even intense combat, leads to post-deployment violence. In fact, two of the estimates in Table 5 suggest that units exposed to combat may serve a protective function: an additional brigade that experienced between 0 and 64 fatalities is associated with a .062 decrease in the probability that a murder occurred in agency $j$ and month $t$; an additional brigade that 
experienced 65 or more fatalities is associated with a 10.4 percent decrease in robberies. These results raise the possibility that experienced soldiers functioned as positive role models, instilling discipline and discouraging aggressive or violent behavior among never-deployed soldiers. ${ }^{29}$ An additional brigade that experienced 65 or more fatalities is also associated with a 5.5 percent decrease in aggravated assaults and a 6.6 percent increase in simple assaults, a pattern of results suggestive of substitution. ${ }^{30}$

\subsection{Recent Exposure to Combat}

Equations (2) and (3) can be modified to examine the effects of recent, as opposed to cumulative, exposure to combat. Although a non-trivial proportion of Fort Carson soldiers had been deployed two or even three times by the end of the Iraq War (Alvarez and Frosch 2009b), there was a fair amount of turnover among active U.S. Army personnel during the period under study. ${ }^{31}$ Given this turnover, a natural modification of (2) is:

$$
\begin{aligned}
& \ln \lambda_{j t}=\alpha_{0}+\alpha_{1}\left(\text { Brigades Not Deployed Past } \text { Year }_{j t}\right)+\alpha_{2} \text { (Brigades Returned Past } \\
& \text { Year } \left._{j t}\right)+\boldsymbol{\beta}^{\prime} \boldsymbol{X}_{j t}+v_{j}+\Theta_{j} \cdot t+\varepsilon_{j t}
\end{aligned}
$$

\footnotetext{
${ }^{29}$ In other words, the presence of previously-deployed units could help socialize less experienced soldiers into what Katz (1990, p. 460) described as the "organizational ethos” of the U.S. Army. According to Katz (1990), this ethos requires soldiers "to act in a highly disciplined, rigidly specified, and coordinated manner and to strictly control any individual behavior that is aggressive, angry or violent” (p. 460).

${ }^{30}$ The hypothesis that $\alpha_{2}$ is larger than $\alpha_{1}$ can be rejected at conventional levels when the outcome is murder, robbery, rape, or aggravated assault. The hypothesis that $\alpha_{3}$ is larger than $\alpha_{1}$ can be rejected at conventional levels when the outcome is murder, robbery, or aggravated assault.

${ }^{31}$ The annual retention rate of active soldiers in the U.S. Army was 82.4 percent in 2005 and 82.7 percent in 2005 (Congressional Budget Office 2006, p. 12). There is evidence that the 3ARC and 3BCT 4-ID struggled to meet reenlistment goals after returning to Fort Carson in 2004 from Iraq (Kelly 2004; Foster 2004).
} 
where, for the treated agencies, Brigades Not Deployed Past Year $r_{j t}$ is equal to the number of combat brigades at Fort Carson in month $t$ that had not been overseas in the past year; Brigades Returned Past Year ${ }_{j t}$ is equal to the number of combat brigades at Fort Carson in month $t$ that had returned from an overseas deployment in the past year. ${ }^{32}$

Table 6 presents the results of this exercise. They are consistent with those presented in Table 4. Specifically, there is little evidence that recently returned combat units represent a threat to public safety: estimates of the relationship between Brigades Returned Past Year ${ }_{j t}$ and violent crime are small and statistically insignificant. In contrast, a one-unit increase in Brigades Not Deployed Past Year $r_{j t}$ is associated with a 0.063 increase in the probability that a murder occurred in agency $j$ and month $t$, an 11.8 percent increase in robberies, and a 6.7 percent increase in aggravated assaults. The hypothesis that $\alpha_{2}$ is larger than $\alpha_{1}$ can be rejected at conventional levels except in the case of property crimes and simple assault. ${ }^{33}$

Finally, in an effort to focus on recent fatalities, we estimate:

$$
\begin{aligned}
& \ln \lambda_{j t}=\alpha_{0}+\alpha_{1}\left(\text { Never-Deployed Brigades }_{j t}\right)+\alpha_{2}\left(\text { Brigades 0-16 Fatalities }_{j t}\right)+ \\
& \alpha_{3}\left(\text { Brigades } \geq 17 \text { Fatalities }_{j t}\right)+\boldsymbol{\beta} \boldsymbol{X}_{j t}+v_{j}+\Theta s \cdot t+\varepsilon_{j t},
\end{aligned}
$$

\footnotetext{
${ }^{32}$ Appendix Figure A3 shows the variation over time in Brigades Not Deployed Past Year $_{j t}$ and Brigades Returned Past Year ${ }_{j t}$.

${ }^{33}$ Appendix Table A3 shows estimates of the relationship between the number of combat brigades that had returned from Iraq in the past three months and violent crime; Appendix Table A4 shows estimates of the relationship between the number of combat brigades that had returned from Iraq in the past 6 months and violent crime. The results are similar to those presented in Table 6. Because soldiers in the U.S. Army are typically eligible for 30 days of leave upon completing a one-year deployment, and because mental health issues such as depression and PTSD often emerge several months after returning home (Bliese et al. 2007), we did not examine the relationship between the number of combat brigades that had been deployed in the past two months and violent crime in El Paso County. During the period under study, soldiers were prevented from leaving the military or moving to new assignments for 90 days after returning from Iraq even if their contractual term of service had ended (Hess 2004; Squitieri 2004; Tice 2009).
} 
where, for the treated agencies, Brigades 0-16 Fatalities $_{j t}$ is equal to the number of brigades at Fort Carson in month $t$ that had experienced between 0 and 16 fatalities when they were last deployed; and Brigades $\geq 17$ Fatalities $_{j t}$ is equal to the number of brigades at Fort Carson in month $t$ that had experienced 17 or more fatalities when they were last deployed. During the period under study, 6 deployments of Fort Carson combat units resulted in 17 or more fatalities. $^{34}$

Increases in never-deployed combat units are associated with more reports of violent crime (Table 7). In contrast, estimates of $\alpha_{2}$ and $\alpha_{3}$ are, with two exceptions, small and statistically insignificant. An additional brigade that sustained between 0 and 16 fatalities is associated with a 2.8 percent increase in simple assaults; an additional brigade that sustained 17 or more fatalities is associated with a 7.0 percent decrease in robberies. ${ }^{35}$

\section{EVIDENCE FROM ARREST RECORDS}

A disadvantage of examining crime reports is that they often do not contain information on the perpetrator, especially when the crime goes unsolved. In this section we take advantage of the fact that all 21 of the Front Range police agencies that contributed data to the analysis of crime reports also provided data to NIBRS with regard to arrests. The arrest data include information on the arresting agency, the date the arrest was made, the type of crime that was committed, and the age and gender of the offender. These data are available from the ICPSR for the period 2001-2007.

\footnotetext{
34 The Fort Carson BCTs deployed a total of 11 times during the period 2001-2009. The 3ARC deployed twice before being permanently relocated to Fort Hood. Appendix Figure A4 shows the variation over time in Brigades $0-16$ Fatalitiesjt, and Brigades $\geq 17$ Fatalitiesjt.

${ }^{35}$ The hypothesis that $\alpha_{2}$ is larger than $\alpha_{1}$ can be rejected at conventional levels when the outcome is murder, robbery, rape, or aggravated assault. The hypothesis that $\alpha_{3}$ is larger than $\alpha_{1}$ can be rejected at conventional levels when the outcome is murder, robbery, rape, aggravated assault, or simple assault.
} 
Table 8 presents estimates of the relationship between Brigades $_{j t}$ and arrests of males 18 years of age and older for violent crimes (i.e., murder, robbery, rape, aggravated assault, and simple assault). Our focus is on this age group because most 17-year-olds, although permitted to enlist with the written permission of their parents, were effectively barred from service due to the Army's strong preference for high school graduates. ${ }^{36}$

The estimated relationship between Brigades $_{j t}$ and arrests of young adult males for violent crimes is positive and significant at the 0.10 level. Specifically, a one-brigade increase in troop levels at Fort Carson is associated with a 2.8 percent increase in arrests of 18- through 29year-olds. The estimated relationship between troop levels and arrests of 30- through 39-yearold males for violent crimes, although positive, is statistically indistinguishable from zero. The estimated relationship between troop levels and arrests of males over the age of 39 for violent crimes is negative, but imprecise.

Table 9 distinguishes between never-deployed and previously deployed combat units. ${ }^{37}$ The results provide further evidence that experienced soldiers do not represent a special threat to public safety. An additional never-deployed brigade at Fort Carson is associated with a 5.4 percent increase in arrests of 18- through 29-year-old males for violent crimes, but the number of previously deployed combat brigades at Fort Carson is essentially unrelated to arrests of males for violent crimes. The hypothesis that previously deployed brigades had a larger effect on

\footnotetext{
${ }^{36}$ Approximately 90 percent of U.S. Army recruits were high school graduates at the outset of the Iraq War; by 2006, this figure had fallen to 82 percent (Congressional Budget Office 2006, p. 6). Seventeen-year-old recruits would have spent at least three months in basic training before being assigned to Fort Carson (Schwartz and Mael 1990; Cavallaro 2007). According to Child Soldiers International (2004, 2008), less than one percent of recruits into the U.S. armed forces were under the age of 18 after completing basic training. Until 2012, women were barred from serving in combat units such as the 3ARC, the 1-6 CAV, and the BCTs (Lopez and Henning 2012). By 2016, all occupational specialties in these units will be open to women (Lopez and Henning 2012).

${ }^{37}$ Appendix Figure A5 shows numbers of never-deployed and deployed combat brigades at Fort Carson for the period 2001-2007.
} 
arrests of 18- through 29-year-old males for violent crime than never-deployed brigades is rejected at the .05 level. $^{38}$

The advantage of examining arrests as opposed to crime reports is that we know the age and sex of the arrestee. Moreover, we can infer that the police viewed the arrestee as culpable. The disadvantage is that arrests are, at least in part, a function of policing effort.

As a test of whether policing effort can explain our results, we regressed the number of sworn officers employed by agency $j$ on troop levels at Fort Carson. Annual data on sworn police officers are from the Uniform Crime Reporting Program and cover the period 20012009. ${ }^{39}$ Estimates from this exercise are generally small and statistically insignificant (Table 10). Although an additional once-deployed brigade is associated with a 3.6 percent increase in sworn officers when agency-specific linear time trends are included in the model, there is no evidence that policing effort increased with Twice-Deployed Brigades $_{j t}$, nor is there evidence of a relationship between brigades that suffered a greater-than-average number of fatalities and policing effort.

\section{CONCLUSION}

During the period 2005-2008, 10 soldiers from Fort Carson were charged by civilian authorities in connection with a series of high-profile murders (Olinger 2008; Philipps 2009;

\footnotetext{
${ }^{38}$ During the period 2001-2007, the median number of casualties suffered by Fort Carson combat units was 51. An additional brigade that suffered between 0 and 51 fatalities is associated with a (statistically insignificant) 0.05 percent decrease in arrests of 18- through 29-year-old males for violent crimes; an additional brigade that suffered 52 or more fatalities is associated with a (statistically insignificant) 3.1 percent increase in arrests of 18- through 29year-old males for violent crimes. These results are reported in Appendix Table A5. Appendix Table A6 presents results from regressing arrests of women 18 years of age and older on troop levels at Fort Carson. This regression, which can be thought of as a falsification test, produced no evidence that troop movements into and out of Fort Carson were related to arrests of women for violent crimes.

${ }^{39}$ These data are available at http://www.fbi.gov/about-us/cjis/ucr/ucr-publications\#Crime. Because they are only available at the year level, we used annual averages of Brigades $s_{j t}$ on the right-hand side of the estimating equation.
} 
Riley and Roeder 2009). Under pressure from the public and policymakers, the U.S. Army responded by conducting a three-month investigation focused on the $2^{\text {nd }}$ Brigade of the $2^{\text {nd }}$ Infantry Division, which had experienced heavy causalities in Iraq. The investigation concluded that soldiers from this unit were especially prone to violent behavior as a result of having been exposed to intense combat in Iraq (U.S. Army Medical Command 2009, p. ES-3).

Fort Carson responded to the murders and subsequent investigation by developing Embedded Behavioral Health teams composed of psychiatrists, psychologists and social workers (Fisher 2009; Carabajal 2011). These teams were tasked with providing counseling to soldiers in the field and evaluating their mental health upon returning home (Carabajal 2011; Collins 2012; Sheehy 2012; Cho-Stutler 2013). The Army is committed to assigning Embedded Behavioral Health teams to all of its combat brigades by 2016 (Collins 2012; Holley 2013).

The current study relies on troop movements into and out of Fort Carson to estimate the relationship between combat exposure and post-deployment violence. Because operational needs and world events determine where U.S. Army units are stationed and when they are deployed (Lyle 2006; Engel et al. 2010; Cesur et al. 2013), these troop movements are arguably exogenous.

Our results suggest that increases in the number of never-deployed combat units are associated with more aggravated assaults, murders, and robberies. For instance, an additional combat brigade based at Fort Carson but not deployed overseas is associated with a 9.1 percent increase in the number of reported robberies and a 7.7 percent increase in the number of reported aggravated assaults. However, there is little evidence that previously deployed brigades increase violent crime. In fact, we find that increases in the number of previously deployed units at Fort Carson are, in some specifications, associated with fewer reports of aggravated assault, murder, 
and robbery. These results raise the possibility that experienced soldiers served as role models, instilling discipline and discouraging aggressive behavior.

The disadvantage of examining crime reports is that they often do not contain information on the perpetrator. To address this shortcoming, we turned to arrest records. Again, we found strong evidence that never-deployed combat units pose a threat to public safety. Specifically, we found that an additional never-deployed brigade at Fort Carson is associated with a 5.4 percent increase in arrests of 18- through 29-year-old males for violent crimes. In contrast, there was no evidence of a relationship between the number of previously deployed brigades at Fort Carson and arrests for violent crime.

The Embedded Behavioral Health program was built on the premise that combat exposure contributes to post-deployment violence (Fisher 2009; Carabajal 2011). Providing psychological counseling to soldiers in the field through Embedded Behavioral Health teams may ultimately yield benefits. However, our results suggest that never-deployed combat units represent a greater threat to public safety than do units that have been exposed to combat.

\section{REFERNCES}

Agnew, Robert. 1992. "Foundation for a General Strain Theory of Delinquency.” Criminology, Vol. 30, No. 1, pp. 47-87.

Akers, Joshua. 2011. "The Unconventional War: Parallels between the Combat Experience in Vietnam and Iraq.” Valley Humanities Review, Spring, pp. 1-20.

Albæk, Karsten, Soren Leth-Petersen, Daniel le Maire, and Torben Tranæs. 2013. "Does Peacetime Military Service Affect Crime?” IZA Discussion Paper No. 7528.

Alvarez, Lizette and Dan Frosch. 2009a. “A Focus on Violence by Returning G.I.’s.” New York Times, January 1. Available at: http://www.nytimes.com/2009/01/02/us/02veterans.html?pagewanted=all 
Alvarez, Lizette and Dan Frosch. 2009b. “Army Studies Possible Link between Combat Duty and Homicides.” New York Times, January 2. Available at:

http://www.nytimes.com/2009/01/02/world/americas/02iht-

vets.1.19051718.html?pagewanted=all.

Angrist, Joshua. 1990. "Lifetime Earnings and the Vietnam Era Draft Lottery: Evidence from Social Security Administrative Records.” American Economic Review, Vol. 80, No. 3, pp. 313336.

Angrist, Joshua and Stacey Chen. 2007. "Long-Term Consequences of Vietnam-Era Conscription: Schooling, Experience, and Earnings.” NBER Working Paper No. 13411.

Ball, J.D., and Thomas H. Peake. 2006. "Brief Psychotherapy in the U.S. Military: Principles and Applications.” In Carrie H. Kennedy and Erica A. Zillner (eds.), Military Psychology: Clinical and Operational Applications. New York: The Guilford Press, pp. 61-73.

Begic, Drazen and Natasa Jokic-Begic. 2001. “Aggressive Behavior in Combat Veterans with Post-Traumatic Stress Disorder.” Military Medicine, Vol. 166, No. 8, pp. 671-676.

Benzel, Lance. 2008. “Carson Soldier Admits he Killed Woman, Sheriff's Office Says.” Colorado Springs Gazette, October 13. Available at:

http://gazette.com/carson-soldier-admits-he-killed-woman-sheriffs-office-says/article/41817.

Benzel, Lance. 2010. “Fort Carson Soldiers Lead Way into Iraq’s 'Uncertain Future'.” Colorado Springs Gazette, March 3, Available at:

http://gazette.com/fort-carson-soldiers-lead-way-into-iraqs-uncertain-future/article/95069.

Benzel, Lance. 2011 “Veterans Court Reclaims those Struggling with War Trauma.” The Colorado Springs Gazette, October 27. Available at:

http://gazette.com/veterans-court-reclaims-those-struggling-with-war-trauma/article/127445.

Bliese, Paul D., Kathleen M. Wright, Amy B. Adler, Jeffrey L. Thomas, and Charles W. Hoge. 2007. “Timing of Postcombat Mental Health Assessments.” Psychological Services, Vol. 4, No. 3, pp. 141-148.

Block, Gordon. 2013. "Fort Drum to Pair Combat Brigades with Behavioral Health Care Teams.” Watertown Daily Times, January 27. Available at: http://www.watertowndailytimes.com/article/20130127/NEWS03/701279860.

Broidy, Lisa. 2001. “A Test of General Strain Theory.” Criminology, Vol. 39, No. 1, pp. 9-36.

Brook, Tom Vanden and Jim Michaels. 2007. "Questions Fill the Air as Bush Speaks on Iraq.” USA Today, January 10. Available at:

http://usatoday30.usatoday.com/news/washington/2007-01-09-iraq-surge-cover_x.htm. 
Byrne, Christina A., and David S. Riggs. 1996. “The Cycle of Trauma: Relationship Aggression in Male Vietnam Veterans with Symptoms of Posttraumatic Stress Disorder.” Violence and Victims, Vol. 11, No. 3, pp. 213-225.

Cameron, A. Colin and Pravin K. Trivedi. 1986. "Econometric Models Based on Count Data: Comparisons and Applications of some Estimators and Tests.” Journal of Applied Econometrics, Vol. 1, No. 1, pp. 29-53.

Cantrell Craig, 2011. “Courtesy Patrol Provides Option.” CSMG.com, August 26. Available at: http://csmng.com/2011/08/26/courtesy-patrol-provides-option/.

Carabajal, Shannon. 2011. "Army Expanding Successful Embedded Behavioral Health Program.”Army.mil, November 17. Available at:

http://www.army.mil/article/69479/.

Card, David, and Gordon B. Dahl. 2011. "Family Violence and Football: The Effect of Unexpected Emotional Cues on Violent Behavior.” Quarterly Journal of Economics, Vol. 126, No. 1, pp. 103-143.

Carpenter, Ted. 2007. “Iraq and Vietnam: Some Unsettling Parallels.” Mediterranean Quarterly, Vol. 18, No. 3, pp. 21-30.

Cavallaro, Gina. 2007. “Basic Training Extended to 10 Weeks.” The Army Times, October 9. Available at:

http://www.armytimes.com/article/20071009/NEWS/710090312/Basic-training-extended-to-10weeks.

Cesur, Resul, Joseph J. Sabia, and Erdal Tekin. 2013. “The Psychological Costs of War: Military Combat and Mental Health.” Journal of Health Economics, Vol. 32, No. 1, pp. 51-65.

Chaffin, Mark, Kelly Kelleher, and Jan Hollenberg. 1996. “Onset of Physical Abuse and Neglect: Psychiatric, Substance Abuse, and Social Risk Factors from Prospective Community Data." Child Abuse and Neglect, Vol. 20, No. 3, pp. 191-203.

Child Soldiers International. 2004. Child Soldiers Global Report 2004 - United States of America. London, United Kingdom: Coalition to Stop the Use of Child Soldiers. Available at: http://www.child-soldiers.org/global_report_reader.php?id=281.

Child Soldiers International. 2008. Child Soldiers Global Report 2008 - United States of America. London, United Kingdom: Coalition to Stop the Use of Child Soldiers. Available at: http://www.child-soldiers.org/global_report_reader.php?id=97.

Cho-Stutler, Laura. 2013. "Staff Voices: Q \& A on the Army’s Embedded Behavioral Health (EBH) Program.” Center for Deployment Psychology, October 7. Available at:

http://www.deploymentpsych.org/blog/staff-voices-q-army\%E2\%80\%99s-embedded-behavioralhealth-ebh-program. 
Chu, James. 2011. Rebuilding Shattered Lives: Treating Complex PTSD and Dissociative Disorders, $2^{\text {nd }}$ Edition. Hoboken, NJ: John Wiley and Sons.

Cohen, Jessica and Pascaline Dupas. 2010. "Free Distribution or Cost-Sharing? Evidence from a Randomized Malaria Prevention Experiment.” Quarterly Journal of Economics, Vol. 125, No. 1, pp. 1-45.

Collins, Dan. 2009. “4 Wives Slain in 6 Weeks at Fort Bragg.” CBS News, February 11.

Available at:

http://www.cbsnews.com/2100-201_162-517033.html.

Collins, Elizabeth M. 2012. “Bringing Behavioral Health to the Troops.” Soldiers, September.

Available at:

http://soldiers.dodlive.mil/2012/09/bringing-behavioral-health-to-the-

troops/\#sthash.cAXYSjnA.dpuf.

Congressional Budget Office. 2006. Recruiting, Retention, and Future Levels of Military

Personnel, Publication Number 2777. Washington DC: The Congress of the United States.

Conley, Dalton and Jennifer Heerwig. 2011. “The War at Home: Effects of Vietnam-Era Military Service on Postwar Household Stability.” American Economic Review: Papers \& Proceedings, Vol. 101, No. 3, pp. 350-354.

Conley, Dalton and Jennifer Heerwig. 2012. "The Long-Term Effects of Military Conscription on Mortality: Estimates from the Vietnam-era Draft Lottery.” Demography, Vol. 49, No. 3, pp. 841-855.

Defense Department. 2007. “Army 3rd Armored Cavalry - Valorous Unit Award.” Army.mil, March 28. Available at:

http://www.army.mil/article/2438.

Dobie, Dorcas J., Daniel R. Kivlahan, Charles Maynard, Kristen R. Bush, Tania M. Davis, Katharine A. Bradley. 2004. "Posttraumatic Stress Disorder in Female Veterans: Association With Self-Reported Health Problems and Functional Impairment.” Archives of Internal Medicine, Vol. 164, No. 4, pp. 394-400.

Dobkin, Carlos and Reza Shabani. 2009. “The Health Effects of Military Service: Evidence from the Vietnam Draft.” Economic Inquiry, Vol. 47, No. 1, pp. 69-80.

Dohrenwend, Bruce P., Yuval Neria, J. Blake Turner, Nicholas Turse, Randall Marshall, Roberto Lewis-Fernandez, and Karestan C. Koenen. 2004. "Positive Tertiary Appraisals and Posttraumatic Stress Disorder in U.S. Male Veterans of the War in Vietnam: The Roles of Positive Affirmation, Positive Reformulation, and Defensive Denial.” Journal of Consulting and Clinical Psychology, Vol. 72, No. 3, pp. 417-433. 
Elbogen, Eric and Sally Johnson. 2009. “The Intricate Link Between Violence and Mental Disorder.” Archives of General Psychiatry, Vol. 66, No. 2, pp. 152-161.

Elbogen, Eric, Sally Johnson, H. Ryan Wagner, Virginia Newton, Christine Timko, Jennifer Vasterling, and Jean Beckham. 2012a. "Protective Factors and Risk Modification of Violence in Iraq and Afghanistan War Veterans.” Journal of Clinical Psychiatry, Vol. 73, No. 6, pp. e767e773.

Elbogen, Eric, Sally Johnson, Virginia Newton, Kristy Straits-Troster, Jennifer Vasterling, H. Ryan Wagner, and Jean Beckham. 2012b. "Criminal Justice Involvement, Trauma, and Negative Affect in Iraq and Afghanistan War Era Veterans.” Journal of Consulting and Clinical Psychology, Vol. 80, No. 6, pp. 1097-1102.

Elbogen, Eric, Sally Johnson, Virginia Newton, Sara Fuller, H. Ryan Wagner, VA Mid-Atlantic MIRECC Registry Workgroup, and Jean Beckham. 2013. "Self-Report and Longitudinal Predictors of Violence in Iraq and Afghanistan War Era Veterans.” Journal of Nervous and Mental Disease, Vol. 201, No. 10, pp. 872-876.

Elder, Glen H., and Elizabeth Clipp. 1989. "Combat Experience and Emotional Health: Impairment and Resilience in Later Life.” Journal of Personality Vol. 57, No. 2, pp. 311-341.

Emert, Rick. 2009. “1-6th Cavalry Prepares for Move to Riley.” Army.mil, February 19, 2009. Available at: http://www.army.mil/article/17119/.

Engel, Rozlyn C., Luke B. Gallagher, and David S. Lyle. 2010. “Military Deployments and Children's Academic Achievement: Evidence from Department of Defense Education Activity Schools.” Economics of Education Review, Vol. 29, No. 1, pp. 73-82.

Eyestone, Lynn and Robert Howell. 1994. “An Epidemiological Study of Attention-Deficit Hyperactivity Disorder and Major Depression in a Male Prison Population.” Bulletin of the American Academy of Psychiatry and the Law, Vol. 22, No. 2, pp. 181-193.

Fava, Maurizio. 1998. “Depression with Anger Attacks.” Journal of Clinical Psychiatry, Vol. 59, Suppl. 18, pp. 18-22.

Fazel, Seena and John Danesh. 2002. "Serious Mental Disorder in 23,000 Prisoners: A Systematic Review of 62 Surveys.” Lancet, Vol. 359, No. 9306, pp. 545-550.

Feeny, Norah C., Lori A. Zoellner, Lee A. Fitzgibbons, and Edna B. Foa. 2000. "Exploring the Roles of Emotional Numbing, Depression, and Dissociation in PTSD.” Journal of Traumatic Stress, Vol.13, No. 3, pp. 489-498.

Ferster, C. B. 1973. “A Functional Analysis of Depression.” American Psychologist, Vol. 28, No. 10, pp. 857-870. 
Finley, Bruce. 2005. “Working, Waiting, Worrying.” Denver Post, April 15. Available at: http://brucefinley.com/page/18/.

Fisher, Devin. 2009. “Study Finds no Link in Homicides.” Fort Carson Mountaineer, Vol. 67 No. 29, p. 1.

Fontana Alan, and Robert Rosenheck. 1998. "Psychological Benefits and Liabilities of Traumatic Exposure in the War Zone.” Journal of Traumatic Stress, Vol. 11, No. 3, pp. 485503.

Forstmeier, Simon, Philipp Kuwert, Carsten Spitzer, Harald J. Freyberger, and Andreas Maercker. 2009. "Posttraumatic Growth, Social Acknowledgment as Survivors, and Sense of Coherence in Former German Child Soldiers of World War II." American Journal of Geriatric Psychiatry, Vol.17, No. 12, pp. 1030-1039.

Foster, Dick. 2004. “GIs Marching Away from Re-Enlistment.” Rocky Mountain News, June 14. Available at:

http://www.freerepublic.com/focus/f-news/1153765/posts.

Foster, Dick. 2006. “3 Fort Carson Soldiers Killed.” Rocky Mountain News, October 21. Available at:

http://m.rockymountainnews.com/news/2006/oct/21/3-fort-carson-soldiers-killed/.

Frosch, Dan, and Lizette Alvarez. 2008. "Mental State of Soldier Questioned.” New York Times, November 20. Available at: http://www.nytimes.com/2008/11/21/us/21army.html?pagewanted=all\&_r=0.

Frosch, Dan. 2008. “3 Buddies Home From Iraq Are Charged With Murdering a 4th.” New York Times, January 12. Available at: http://www.nytimes.com/2008/01/12/us/12soldier.html?pagewanted\%3Dall\&_r=0.

Galiani, Sebastian, Martin Rossi, and Ernesto Schargrodsky. 2011. "Conscription and Crime: Evidence from the Argentine Draft Lottery.” American Economic Journal: Applied Economics, Vol. 3, No. 2, pp. 119-136.

Galovskia, Tara, and Judith A. Lyons. 2004. "Psychological Sequelae of Combat Violence: A Review of the Impact of PTSD on the Veteran's Family and Possible Interventions." Aggression and Violent Behavior, Vol. 9, No. 5, pp. 477-501.

Gonzales, Oscar R. 2009. "Economic Development Assistance for Communities Affected by Employment Changes Due to Military Base Closures (BRAC)." Washington DC: Congressional Research Service Report RL34709.

Gould, Eric, Bruce Weinberg, and David Mustard. 2002. "Crime Rates and Local Labor Market Opportunities in the United States: 1979-1997.” Review of Economics and Statistics, Vol. 84, No. 1, pp. 45-61. 
Grey, Philip 2013. “101st Airborne Vastly Expands Care for 'Unseen Wounds’” The Army Times, April 30. Available at:

http://www.armytimes.com/article/20130430/NEWS/304300005/101st-Airborne-vastly-expandscare-unseen-wounds-.

Grootendorst, Paul V. 2002. “A Comparison of Alternative Models of Prescription Drug Utilization.” In Andrew M. Jones and Owen O’Donnell (eds.), Econometric Analysis of Health Data, Hoboken, NJ: John Wiley and Sons, Ltd, pp. 73-86.

Grossman, Dave, Loren Christensen, and Gavin de Becker. 2008. On Combat: The Psychology and Physiology of Deadly Conflict in War and in Peace. Millstadt, IL: Warrior Science Publications.

Hames, Jacqueline M. 2009. "Resiliency Training to be Given Army-Wide.” Army News Service, October 6. Available at:

http://www.nationalguard.mil/news/archives/2009/10/100809-Resiliency.aspx.

Henley, Kyle and Tom Roeder. 2005. “Carson Soldier Kills Wife, Himself.” Colorado Springs Gazette, August 5. Available at:

http://gazette.com/article/8332.

Hess, Pamela. 2004. “Army Extends Stop-Loss Order.” United Press International, June 2. Available at:

http://www.upi.com/Business_News/Security-Industry/2004/06/02/Army-extends-stop-lossorder/UPI-43651086200189/.

Holley, Rayna. 2013. “Clinics to Offer Behavioral Health Services.” Northwest Guardian, June 27. Available at: http://www.nwguardian.com/2013/06/27/15784/clinics-to-offer-behavioralhealth.html.

Hoge, Charles, Carl Castro, Stephen Messer, Dennis McGurk, Dave Cotting, and Robert Koffman. 2004. "Combat Duty in Iraq and Afghanistan, Mental Health Problems, and Barriers to Care.” New England Journal of Medicine, Vol. 351, No. 1, pp. 13-22.

Hoge, Charles W., Jennifer L. Auchterlonie, and Charles S. Milliken. 2006. "Mental Health Problems, Use of Mental Health Services, and Attrition from Military Service after Returning from Deployment to Iraq or Afghanistan.” Journal of the American Medical Association, Vol. 295, No. 9, pp. 1023-1032.

Hooker, Mark A. and Michael M. Knetter. 2001. "Measuring the Economic Effects of Military Base Closures.” Economic Inquiry, Vol. 39, No. 4, pp. 583-598.

Horgan, John. 2011. "Beware the Military-Psychological Complex: A \$125-million Program to Boost Soldiers’ “Fitness” Raises Ethical Questions.” Scientific American, April 18. Available at: 
http://blogs.scientificamerican.com/cross-check/2011/04/18/beware-the-military-psychologicalcomplex-a-125-million-program-to-boost-soldiers-fitness-raises-ethical-questions/.

Huspeni, Dennis and Tom Roeder. 2007. “Coming Home Changed.” Colorado Springs Gazette, December 22. Available at: http://gazette.com/coming-home-changed/article/31171.

Huspeni, Dennis. 2006. "Soldier Convicted of Manslaughter.” Colorado Springs Gazette, April 7. Available at: http://gazette.com/soldier-convicted-of-manslaughter/article/9908.

Ingram, Andrew. 2009. "New Behavioral Health Programs Aims to Heal.” CSMG.Com, August 27. Available at: http://csmng.com/2009/08/27/new-behavioral-health-programs-aims-to-heal/.

Ingram, Andrew. 2012. "Fort Carson Courtesy Patrol Safeguards Soldiers." Army.mil, June 27 . Available at:

http://www.army.mil/article/82689/Fort_Carson_Courtesy_Patrol_safeguards_Soldiers/.

Jacob, Brian, Lars Lefgren, and Enrico Moretti. 2007. "The Dynamics of Criminal Behavior: Evidence from Weather Shocks.” Journal of Human Resources, Vol. 42, No. 3, pp. 489-527.

Jakupcak, Matthew, Daniel Conybeare, Lori Phelps, Stephen Hunt, Hollie A. Holmes, Bradford Felker, Michele Klevens, Miles E. McFall. 2007. "Anger, Hostility, and Aggression among Iraq and Afghanistan War Veterans Reporting PTSD and Subthreshold PTSD." Journal of Traumatic Stress, Vol. 20, No. 6, pp. 945-954.

Katz, Pearl. 1990. "Emotional Metaphors, Socialization, and Roles of Drill Sergeants." Ethos, Vol. 18, No. 4, pp. 457-480.

Kelly, David. 2004. “Army Forcing Reenlistment, Soldiers Say.” Los Angeles Times, October 3. Available at:

http://articles.latimes.com/2004/oct/03/nation/na-enlist3.

Killgore, William D.S., Dave I. Cotting, Jeffrey L. Thomas, Anthony L. Cox, Dennis McGurk, Alexander H. Vo, Carl A. Castro, and Charles W. Hoge. 2008. "Post-Combat Invincibility: Violent Combat Experiences are Associated with Increased Risk-Taking Propensity Following Deployment.” Journal of Psychiatric Research, Vol. 42, No. 13, pp. 1112-1121.

Kocherga, Angela. 2013. "Fort Bliss Suicide Rate Declines to Army's Lowest.” KVEU News, February 5. Available at: http://www.kvue.com/news/189921231.html.

Koenig, Harold G., Kenneth I. Pargament, and Julie Nielsen. 1998. "Religious Coping and Health Status in Medically Ill Hospitalized Older Adults.” Journal of Nervous and Mental Disease, Vol. 186, No. 9, pp. 513-521. 
Komarow, Steven. 2005. “Vietnam Vets in Iraq See ‘Entirely Different War’.” USA Today, June 20. Available at:

http://usatoday30.usatoday.com/news/world/iraq/2005-06-20-iraq-vietnam-vets_x.htm.

Kristof, Nicholas. 2012. “When War Comes Home.” New York Times, November 9. Available at:

http://www.nytimes.com/2012/11/11/opinion/sunday/kristof-when-war-comes-home.html? r=0.

Lester, Paul, P.D. Harms, Denise Bulling, Mitchel Herian, and Seth Spain. 2011. "Evaluation of Relationships Between Reported Resilience and Outcomes - Report \#1: Negative Outcomes (Suicide, Drug Use, \& Violent Crimes).” TKC Global Solutions LLC, Anchorage, AK.

Lindo, Jason and Charles Stoecker. Forthcoming. "Drawn into Violence: Evidence on 'What Makes a Criminal’ From the Vietnam Draft Lotteries.” Economic Inquiry.

Linley, P. Alex, and Stephen Joseph. 2004. "Positive Change Following Trauma and Adversity: A Review.” Journal of Traumatic Stress, Vol. 17, No. 1, pp. 11-21.

Lopez, Todd, and Julia Henning. 2013. “Army Describes Plans for Integrating Women into Combat.” Army.mil, June 18. Available at:

http://www.army.mil/article/105814/.

Lorge, Elizabeth M. 2007. “Army Announces Stationing Decisions for New Troops.” Army News Service, December 19. Available at:

http://www.army.mil/article/6683/.

Lowary, Jake. 2010. “Fort Campbell Soldier Charged in Wife’s Death.” The Leaf-Chronicle, December 10. Available at: http://www.theleafchronicle.com/article/20101210/NEWS08/12100319.

Luning, Ernest. 2009. “Udall Grills Army Sec. Nominee on Fort Carson Killings, Piñon Canyon.” Colorado Independent, July 30. Available at:

http://www.coloradoindependent.com/34347/udall-grills-army-secretary-nominee-on-fortcarson-killings-pinon-canyon.

Lyle, David S. 2006. “Using Military Deployments and Job Assignments to Estimate the Effect of Parental Absences and Household Relocations on Children's Academic Achievement.” Journal of Labor Economics, Vol. 24, No. 2, pp. 319-350.

MacLean, Alair, and Nicholas L. Parsons. 2010. “Unequal Risk: Combat Occupations in the Volunteer Military.” Sociological Perspectives, Vol. 53, No. 3, pp. 347-372. 
MacManus, Deirdre, Kimberlie Dean, M. Al Bakir, A. C. Iversen, Lisa Hull, Tom Fahy, Simon Wessely, and Nicola T. Fear. 2012. "Violent Behaviour in UK Military Personnel Returning Home after Deployment.” Psychological Medicine, Vol. 42, No. 8, pp. 1663-1673.

MacManus, Deirdre, Kimberlie Dean, Margaret Jones, Roberto J Rona, Neil Greenberg, Lisa Hull, Tom Fahy, Simon Wessely, and Nicola T. Fear. 2013. "Violent Offending by UK Military Personnel Deployed to Iraq and Afghanistan: A Data Linkage Cohort Study.” The Lancet, Vol. 381, No. 9870, pp. 907-917.

Maguen, Shira, Dawne S. Vogt, Lynda A. King, Daniel W. King, and Brett T. Litz. 2006. "Posttraumatic Growth Among Gulf War I Veterans: The Predictive Role of DeploymentRelated Experiences and Background Characteristics.” Journal of Loss and Trauma, Vol. 11, No. 5, pp. 373-388.

Main, Frank. 2005. “US GIs - Killers On and Off the Battlefield?” Rense.com, February 2. Available at:

http://www.rense.com/general63/GIS.HTM.

Maiuro, Roland, Timothy Cahn, Peter Vitaliano, Barbara Wagner, and Joan Zegree. 1988. "Anger, Hostility, and Depression in Domestically Violent Versus Generally Assaultive Men and Nonviolent Control Subjects.” Journal of Consulting and Clinical Psychology, Vol. 56, No. 1, pp. 17-23.

Mason, John W., Sheila Wang, Rachel Yehuda, Sherry Riney, Dennis S. Charney, and Steven M. Southwick. 2001. "Psychogenic Lowering of Urinary Cortisol Levels Linked to Increased Emotional Numbing and a Shame-Depressive Syndrome in Combat-Related Posttraumatic Stress Disorder.” Psychosomatic Medicine, Vol. 63, No. 3, pp. 387-401.

Mazerolle, Paul and Alex Piquero. 1997. "Violent Responses to Strain: An Examination of Conditioning Influences.” Violence and Victims, Vol. 12, No. 4, pp. 323-343.

McDowall, David, Colin Loftin, and Matthew Pate. 2012. "Seasonal Cycles in Crime, and Their Variability.” Journal of Quantitative Criminology, Vol. 28, No. 3, pp. 389-410.

McFall, Miles, Priscilla Mackay, and Dennis Donovan. 1992. "Combat-Related Posttraumatic Stress Disorder and Severity of Substance Abuse in Vietnam Veterans.” Journal of Studies on Alcohol, Vol. 53, No. 4, pp. 357-363.

McMillen, J. Curtis, and Cynthia Loveland Cook. 2003. "The Positive By-Products of Spinal Cord Injury and their Correlates.” Rehabilitation Psychology, Vol. 48, No. 2, pp. 77-85.

Milburn, John. 2005. “Fort Riley Soldiers Begin Appeals.” Lawrence Journal-World, June 14. Available at: http://www2.ljworld.com/news/2005/jun/14/fortrileysoldiers/.

Miles, Donna. 2005. “BRAC Deadline Expires; DoD to Begin Closures, Realignments.” 
American Forces Press Service, November 9. Available at:

http://www.defense.gov/News/NewsArticle.aspx?ID=18352.

Millerrodgers, Monica. 2010. “Comprehensive Soldier Fitness Marks Change in Army Culture.” Army.mil, September 27. Available at:

http://www.army.mil/article/45723/comprehensive-soldier-fitness-marks-change-in-army-

culture/.

Milliken, Charles S., Jennifer L. Auchterlonie, and Charles W. Hoge. 2007. "Longitudinal Assessment of Mental Health Problems Among Active and Reserve Component Soldiers

Returning From the Iraq War.” Journal of the American Medical Association, Vol. 298, No. 18, pp. 2141-2148.

Mills, Katherine L., Maree Teesson, Joanne Ross, and Lorna Peters. 2006. “Trauma, PTSD, and Substance Use Disorders: Findings from the Australian National Survey of Mental Health and Well-Being.” American Journal of Psychiatry, Vol. 163, No. 4, pp. 652-658.

Mitchell, Kirk. 2008a. “GI Murder Suspect Got Counseling.” Denver Post, October 16.

Available at:

http://www.denverpost.com/news/ci_10730616?source=pkg.

Mitchell, Kirk. 2008b. “Salazar: Review GI Violence.” Denver Post, October 19. Available at: http://www.denverpost.com/news/ci_10758345?source=pkg.

Nestler, Eric J., Michel Barrot, Ralph J. DiLeone, Amelia J. Eisch, and Stephen J. Gold, and Lisa M. Monteggia. 2002. “Neurobiology of Depression.” Neuron, Vol. 34, pp. 13-25.

Nutt, David Koen Demyttenaere, Zoltan Janka, Trond Aarre, Michel Bourin, Pier Luigi Canonico, Jose Luis Carrasco, and Steven Stahl. 2007. "The Other Face of Depression, Reduced Positive Affect: The Role of Catecholamines in Causation and Cure.” Journal of Psychopharmacology, Vol. 21 No. 5, pp. 461-471.

Olinger, David. 2008. “Deadly Duty for Fort Carson.” Denver Post, November 16. Available at: http://www.denverpost.com/frontpage/ci_10996605.

Park, Crystal L., Lawrence H. Cohen, and Renee L. Murch. 1996. "Assessment and Prediction of Stress-Related Growth.” Journal of Personality, Vol. 64, pp. 71-105.

Philipps, Dave. 2009. “Casualties of War, Part II: Warning Signs.” Colorado Springs Gazette, July 24. Available at:

http://gazette.com/article/59091.

Poppert, Patrick E., and Henry W. Herzog Jr., 2003. "Force Reduction, Base Closure, and the Indirect Effects of Military Installations on Local Employment Growth.” Journal of Regional Science, Vol. 43, No. 3, pp. 459-482. 
Raphael, Steven and Rudolf Winter-Ebmer. 2001. "Identifying the Effect of Unemployment on Crime.” Journal of Law and Economics, Vol. 44, No. 1, pp. 259-283.

Ricks, Thomas E. 2006. “It Looked Weird and Felt Wrong.” Washington Post, July 24, p. A01. Available at:

http://www.washingtonpost.com/wpdyn/content/article/2006/07/23/AR2006072300495_pf.html.

Ridder, Knight. 2007. “War Stresses Linked to Soldiers' Crimes.” Military.com, December 25. Available at: http://www.military.com/NewsContent/0,13319,158912,00.html.

Riggs, David S. Christina A. Byrne, Frank W. Weathers, and Brett T. Litz. 1998. "The Quality of the Intimate Relationships of Male Vietnam Veterans: Problems Associated with Posttraumatic Stress Disorder.” Journal of Traumatic Stress, 11, 87-101.

Riley, Michael, and Tom Roeder. 2009. "Intense Combat Tied to Homicides by Ft. Carson GIs.” Denver Post, July 16. Available at: http://www.denverpost.com/frontpage/ci_12847489?source=pkg.

Robson, Seth. 2004. “After Iraq, 2nd BCT will Call Fort Carson Home.” Stars and Stripes, September 26. Available at: http://www.stripes.com/news/after-iraq-2nd-bct-will-call-fort-carson-home-1.24504.

Roeder, Tom. 2004. "Special Forces Unit at Ft. Carson Secretly Deployed to Iraq.” Colorado Springs Gazette, December 6. Available at: http://www.ar15.com/archive/topic.html?b=1\&f=5\&t=302350.

Roeder, Tom. 2013. “Iraq: Ten Years Later.” Colorado Springs Gazette, March 15. Available at: http://gazette.com/iraq-ten-years-later/article/152318.

Rohlfs, Chris. 2010. “Does Combat Exposure Make You a More Violent or Criminal Person?” Journal of Human Resources, Vol. 45, No. 2, pp. 271-300.

Rose, Maureen. 2012. "Behavioral Health Counseling Effective, Expanding Services.” The Gold Standard, September 20. Available at: http://www.fkgoldstandard.com/content/behavioral-health-counseling-effective-expanding$\underline{\text { services }}$

Samper, Rita E., Casey T. Taft, Daniel W. King, and Lynda A. King. 2004. "Posttraumatic Stress Disorder Symptoms and Parenting Satisfaction among a National Sample of Male Vietnam Veterans.” Journal of Traumatic Stress, Vol.17, No. 4, pp. 311-315.

Schnurr, Paula P., Carole A. Lunney, Michelle J. Bovin, and Brian P. Marx. 2009. "Posttraumatic Stress Disorder and Quality of Life: Extension of Findings to Veterans of the Wars in Iraq and Afghanistan.” Clinical Psychology Review, Vol. 29, No. 8, pp. 727-735. 
Schwartz, Amy C. and Fred A. Mael. 1990. “An Introduction to the Army Personnel System.” U.S. Army Research Institute for the Behavioral and Social Sciences, Special Report S-19. Available at:

http://oai.dtic.mil/oai/oai?verb=getRecord\&metadataPrefix=html\&identifier=ADA247465.

Scioli, Erica, John Otis, and Terence Keane. 2010. "Psychological Problems Associated with Operation Enduring Freedom/Operation Iraqi Freedom Deployment.” American Journal of Lifestyle Medicine, Vol. 4, No. 4, pp. 349-359.

Sharpley, Christopher F., and Vicki Bitsika. 2010. "Joining the Dots: Neurobiological Links in a Functional Analysis of Depression.” Behavioral and Brain Functions, Vol. 6, No. 73.

Sheehy, Gail. 2012. “Army's Huge Culture Shift: No Shame in Mental Health Help.” USA Today, July 5. Available at:

http://usatoday30.usatoday.com/news/military/story/2012-07-05/soldiers-PTSD-suicide-therapyfort-carson/56042102/1.

Siminski, Peter, Simon Ville, and Alexander Paull. 2013. "Does the Military Train Men to Be Violent Criminals? New Evidence from Australia’s Conscription Lotteries.” IZA Discussion Paper No. 7152.

Slevin, Colleen 2005. “Ft. Carson Gaining New Soldiers.” Denver Post, July 27. Available at: http://www.denverpost.com/news/ci_2894415.

Smith, Tyler C., Margaret A. K. Ryan, Deborah L. Wingard, Donald J. Slymen, James F. Sallis, and Donna Kritz-Silverstein. 2008. "New Onset and Persistent Symptoms of Post-Traumatic Stress Disorder Self Reported After Deployment and Combat Exposures: Prospective Population Based US Military Cohort Study.” British Medical Journal, Vol. 336, No. 7640, pp. 366-371.

Smith, L. Christopher. 2009. “The Fort Carson Murder Spree.” Rolling Stone, November 12. Available at:

http:/www.rollingstone.com/politics/news/the-fort-carson-murder-spree-20091112?page=2.

Solomon, Zahava, and Rachel Dekel. 2007. "Posttraumatic Stress Disorder and Posttraumatic Growth among Israeli Ex-POWs.” Journal of Traumatic Stress, Vol. 20, No. 3, pp. 303-312.

Songtag, Deborah, and Lizette Alvarez. 2008. “Across America, Deadly Echoes of Foreign Battles.” New York Times, January 13.

Spelman, Juliette F., Stephen C. Hunt, Karen H. Seal, and A. Lucile Burgo-Black. 2012. "Post Deployment Care for Returning Combat Veterans.” Journal of General Internal Medicine, Vol. 27, No. 9, pp. 1200-1209.

Squitieri, Tom. 2004. “Army Expanding 'Stop Loss' Order to Keep Soldiers from Leaving.” USA Today, January 5. Available at: 
http://usatoday30.usatoday.com/news/nation/2004-01-05-army-troops_x.htm.

Sreenivasan, Shoba, Thomas Garrick, James McGuire, Daniel E. Smee, Daniel Dow, and Daniel Woehl. 2013. "Critical Concerns in Iraq/Afghanistan War Veteran-Forensic Interface: CombatRelated Postdeployment Criminal Violence.” Journal of the American Academy of Psychiatry and the Law, Vol. 41, No. 2, pp. 263-273.

Swendsen, Joel and Kathleen Merikangas. 2000. "The Comorbidity of Depression and Substance Use Disorders.” Clinical Psychology Review, Vol. 20, No. 2, pp. 173-189.

Tang, Jeff. 2010. "Ex-Wife of Soldier Accused of Murder Talks of Violent Past.” NewsChannel5.com, December 27. Available at:

http://www.newschannel5.com/story/13746496/ex-wife-of-soldier-accused-of-murder-talks-ofviolent-past.

Tedeschi, Richard G., and Lawrence G. Calhoun. 1996. "The Posttraumatic Growth Inventory: Measuring the Positive Legacy of Trauma.” Journal of Traumatic Stress, Vol. 9, No. 3, pp. 455471.

Tice, Jim. 2009. “Active Stop-Loss Policy Adjusted.” Army Times, August 23. Available at: http://www.armytimes.com/article/20090823/NEWS/908230313/Active-stop-loss-policyadjusted.

Tyson, Ann Scott, and Josh White. 2007. "Strained Army Extends Tours To 15 Months." Washington Post, April 12. Available at: http://www.washingtonpost.com/wp-dyn/content/article/2007/04/11/AR2007041100615.html.

United States Army Medical Command, Office of the Surgeon General. 2009. "Epidemiologic Consultation No. 14-HK-OB1U-09, Investigation of Homicides at Fort Carson, Colorado, November 2008-May 2009, Final Report.” Available at:

http://www.armymedicine.army.mil/reports/FinalRedactedEpicon.

United States Government Accountability Office. 2009. "Military Base Realignments and Closures: DOD Faces Challenges in Implementing Recommendations on Time and Is Not Consistently Updating Savings Estimates.” Washington DC: GAO-09-217

Warner, Joel. 2010. “Can a Veterans Court Help Former GIs find Justice Here at Home?” Denver Westword, Feb 4. Available at:

http://www.westword.com/2010-02-04/news/can-a-veterans-court-help-former-gis-find-justicehere-at-home/.

Werthmann, Kelly. 2012. “Special Court Helps Local Veterans.” Fox21News.com, March 8. Available at: http://www.fox21news.com/news/story.aspx?id=728429. 
Wirthman, Lisa. 2012. "Emotional Casualties of War.” Denver Post, April 27. Available at: http://www.denverpost.com/opinion/ci_20490749/emotional-casualties-war.

Zeidner, J., D. Scholarios, and C.D. Johnson. 2001. "Classification Techniques for Person-Job Matching: An Illustration Using the US Army.” Kybernetes, Vol. 30, No. 7/8, pp. 984-1005.

Zoroya, Gregg. 2010. "Repeated Deployments Weigh Heavily on U.S. Troops.” USA Today, January 1. Available at:

http://usatoday30.usatoday.com/news/military/2010-01-12-four-army-war-tours_N.htm. 
Figure 1. Number of Combat Brigades at Fort Carson, 2001-2009

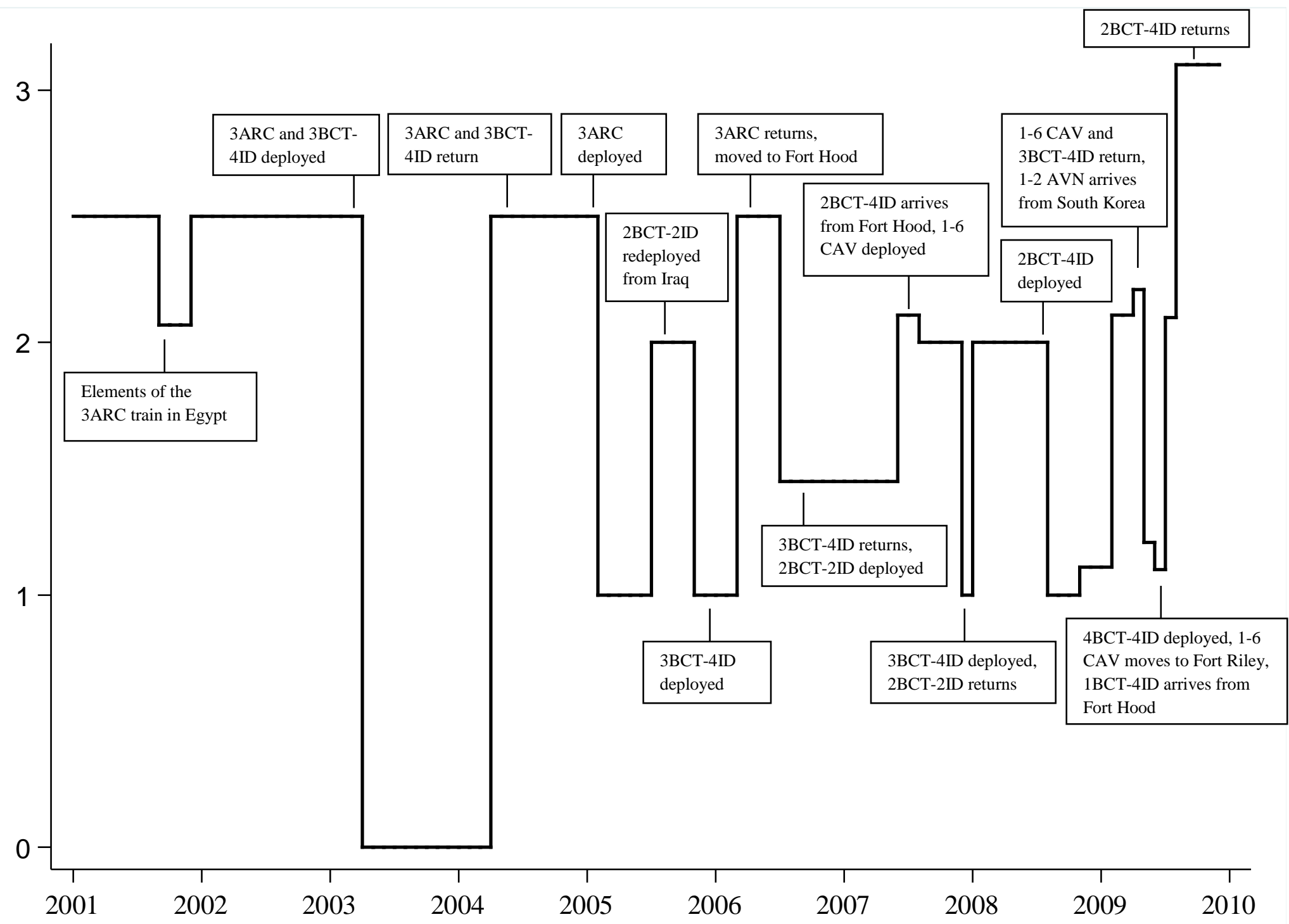


Figure 2a. Troop Levels and Violent Crime El Paso County Sheriff's Office

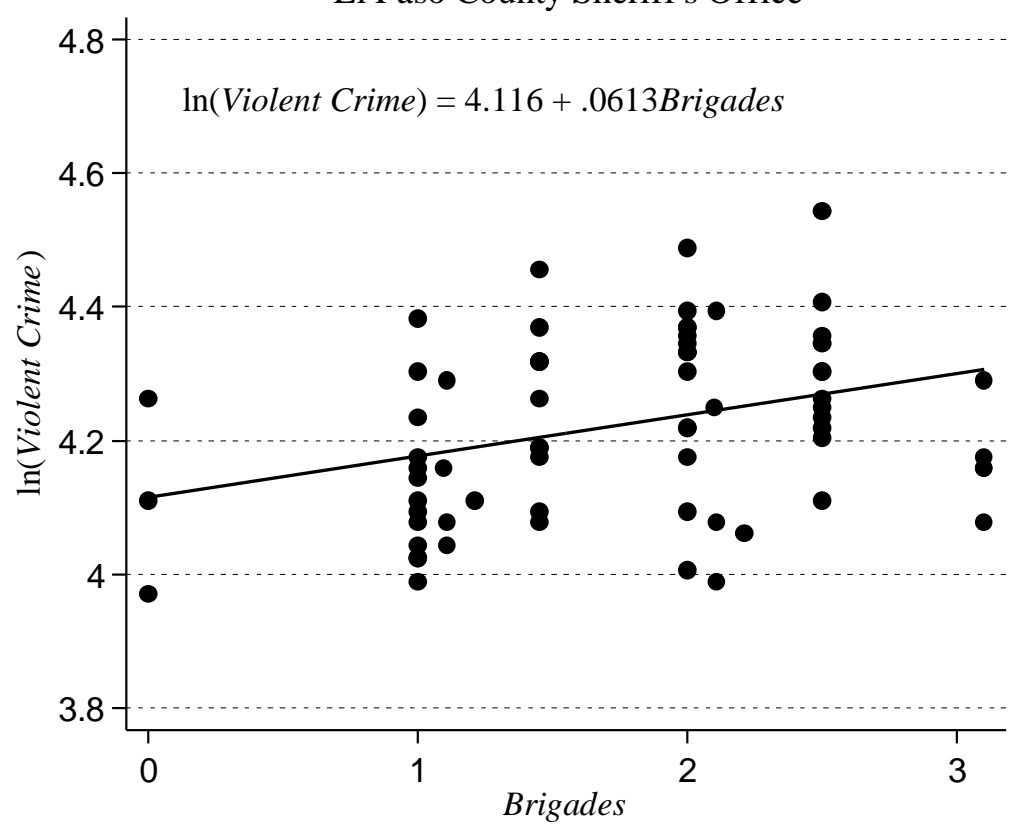

Figure 2b. Troop Levels and Violent Crime Colorado Springs Police Department

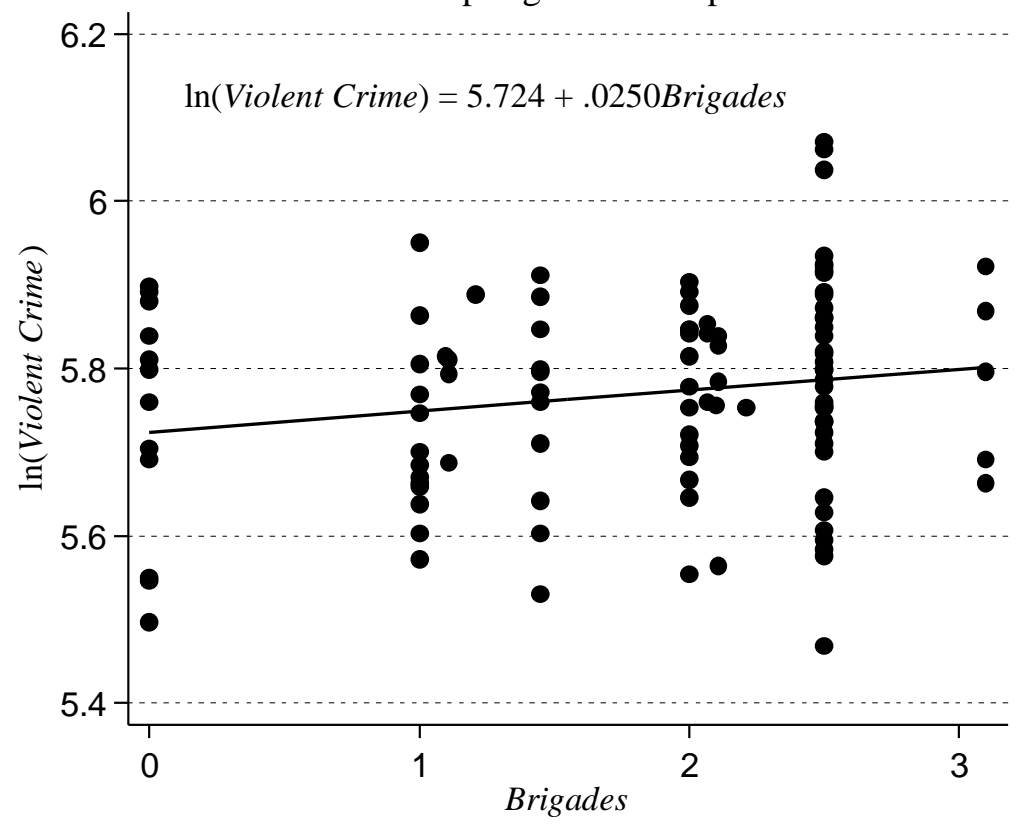


Table 1. Troop Levels at Fort Carson and Crime

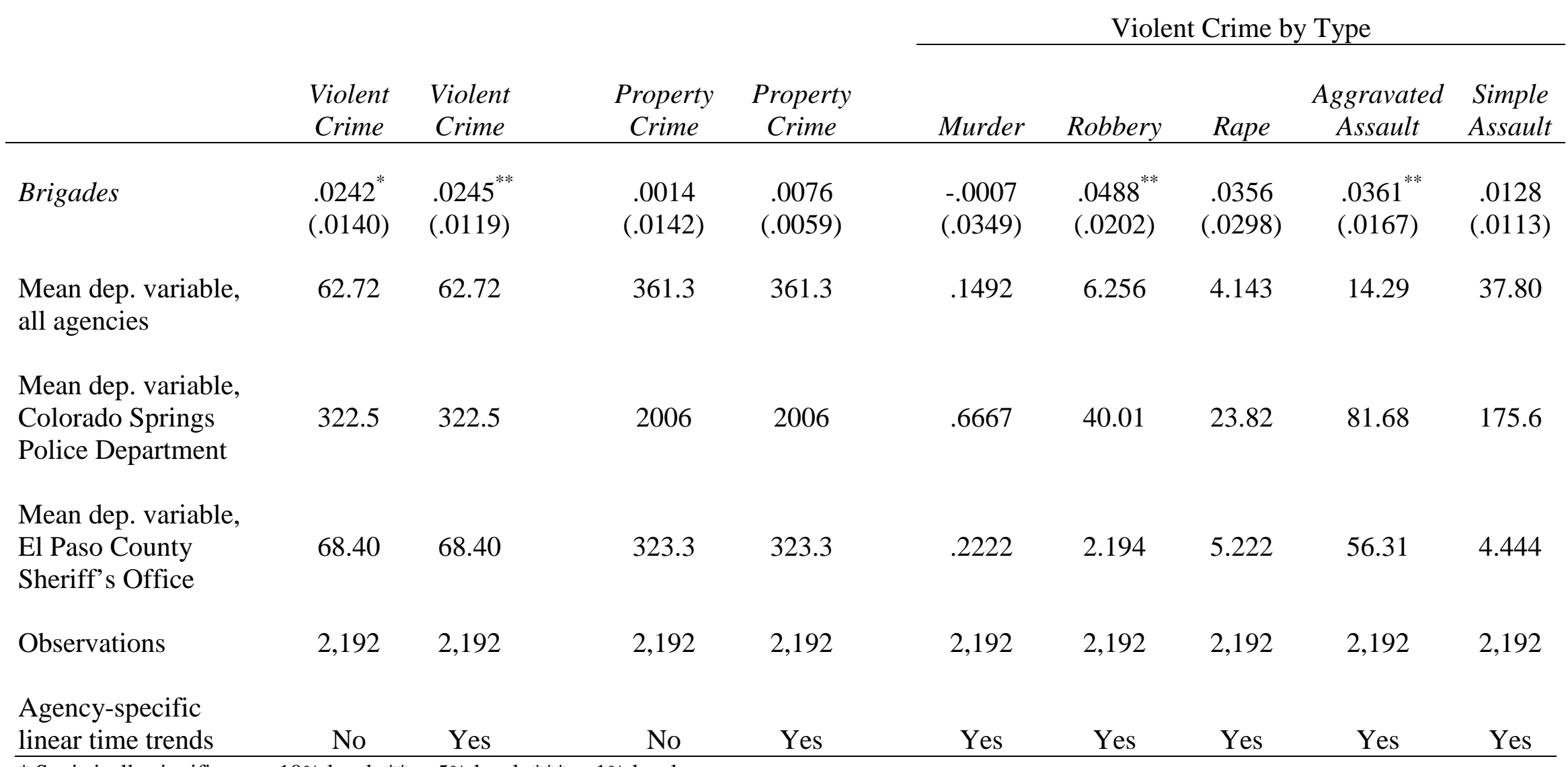

* Statistically significant at $10 \%$ level; ** at $5 \%$ level; *** at $1 \%$ level

Notes: The estimated relationship between combat brigades at Fort Carson and murders is from an OLS regression. All other estimated coefficients are from Poisson regressions. Data on crime reports at the agency-month level are from the National Incident Based Reporting System and cover the period 2001-2009. Property crimes include arson, burglary, larceny, motor vehicle theft, stolen property and vandalism. Controls include 8 year indicators, 11 month indicators, 20 agency indicators, the natural log of the agency population, and the county unemployment rate. Standard errors (in parentheses) are corrected for clustering at the county-year level. 
Table 2. Did Violent Crime Change Before Deployments/Redeployments?

\begin{tabular}{|c|c|c|c|c|c|c|}
\hline & $\begin{array}{l}\text { Violent } \\
\text { Crime }\end{array}$ & $\begin{array}{c}\text { Violent } \\
\text { Crime }\end{array}$ & $\begin{array}{l}\text { Violent } \\
\text { Crime }\end{array}$ & $\begin{array}{l}\text { Violent } \\
\text { Crime }\end{array}$ & $\begin{array}{l}\text { Violent } \\
\text { Crime }\end{array}$ & $\begin{array}{l}\text { Violent } \\
\text { Crime }\end{array}$ \\
\hline Brigades (12 month lead) & & & & $\ldots$ & $\ldots$ & $\begin{array}{c}-.0094 \\
(.0161)\end{array}$ \\
\hline Brigades (9 month lead) & $\ldots$ & $\ldots$ & $\ldots$ & $\ldots$ & $\begin{array}{c}-.0071 \\
(.0165)\end{array}$ & $\begin{array}{c}-.0037 \\
(.0116)\end{array}$ \\
\hline Brigades (6 month lead) & $\ldots$ & $\ldots$ & ... & $\begin{array}{c}.0071 \\
(.0095)\end{array}$ & $\begin{array}{c}.0102 \\
(.0082)\end{array}$ & $\begin{array}{c}.0100 \\
(.0080)\end{array}$ \\
\hline Brigades (3 month lead) & $\ldots$ & $\ldots$ & $\begin{array}{c}.0194 \\
(.0142)\end{array}$ & $\begin{array}{c}.0156 \\
(.0137)\end{array}$ & $\begin{array}{c}.0153 \\
(.0134)\end{array}$ & $\begin{array}{c}.0168 \\
(.0137)\end{array}$ \\
\hline Brigades (2 month lead) & $\ldots$ & $\begin{array}{c}.0045 \\
(.0129)\end{array}$ & $\begin{array}{c}-.0118 \\
(.0174)\end{array}$ & $\begin{array}{c}-.0108 \\
(.0162)\end{array}$ & $\begin{array}{c}-.0110 \\
(.0162)\end{array}$ & $\begin{array}{c}-.0112 \\
(.0165)\end{array}$ \\
\hline Brigades (1 month lead) & $\begin{array}{c}-.0065 \\
(.0091)\end{array}$ & $\begin{array}{c}-.0104 \\
(.0118)\end{array}$ & $\begin{array}{c}-.0097 \\
(.0122)\end{array}$ & $\begin{array}{c}-.0098 \\
(.0121)\end{array}$ & $\begin{array}{c}-.0090 \\
(.0120)\end{array}$ & $\begin{array}{c}-.0107 \\
(.0113)\end{array}$ \\
\hline Brigades & $\begin{array}{l}.0296^{* *} \\
(.0135)\end{array}$ & $\begin{array}{l}.0301^{* *} \\
(.0132)\end{array}$ & $\begin{array}{l}.0317^{* *} \\
(.0125)\end{array}$ & $\begin{array}{l}.0317^{* * *} \\
(.0119)\end{array}$ & $\begin{array}{l}.0303^{* *} \\
(.0119)\end{array}$ & $\begin{array}{l}.0279^{* *} \\
(.0118)\end{array}$ \\
\hline Observations & 2,192 & 2,192 & 2,192 & 2,192 & 2,192 & 2,192 \\
\hline
\end{tabular}

* Statistically significant at $10 \%$ level; ** at $5 \%$ level; *** at $1 \%$ level

Notes: Estimated coefficients are from Poisson regressions. Data on crime reports at the agency-month level are from the National Incident Based Reporting System and cover the period 2001-2009. Controls include 8 year indicators, 11 month indicators, 20 agency indicators, agency-specific linear time trends, the natural log of the agency population, and the county unemployment rate. Standard errors (in parentheses) are corrected for clustering at the county-year level. 
Table 3. Robustness Checks (Violent Crime)

\begin{tabular}{|c|c|c|c|c|c|c|c|}
\hline & OLS & $\begin{array}{l}\text { Negative } \\
\text { binomial }\end{array}$ & $\begin{array}{c}\text { El Paso County } \\
\text { Sherriff's Office } \\
\text { excluded }\end{array}$ & $\begin{array}{c}\text { Colorado } \\
\text { Springs PD } \\
\text { excluded }\end{array}$ & $\begin{array}{c}\text { Restricted to } \\
\text { agencies } \\
\text { covering } \\
\text { populations } \\
>50,000 \\
\end{array}$ & $\begin{array}{l}\text { Month-year } \\
\text { fixed effects } \\
\end{array}$ & $\begin{array}{c}\text { SEs clustered at } \\
\text { agency level }\end{array}$ \\
\hline Brigades & $\begin{array}{l}.0315^{* *} \\
(.0153)\end{array}$ & $\begin{array}{l}.0307^{* *} \\
(.0131)\end{array}$ & $\begin{array}{l}.0208^{*} \\
(.0123)\end{array}$ & $\begin{array}{l}.0603^{* * *} \\
(.0224)\end{array}$ & $\begin{array}{l}.0250^{* *} \\
(.0120)\end{array}$ & $\begin{array}{l}.0313^{* * *} \\
(.0097)\end{array}$ & $\begin{array}{l}.0245^{* *} \\
(.0107)\end{array}$ \\
\hline Observations & 2,063 & 2,192 & 2,120 & 2,084 & 923 & 2,192 & 2,192 \\
\hline
\end{tabular}

* Statistically significant at $10 \%$ level; ** at $5 \%$ level; *** at $1 \%$ level

Notes: Unless otherwise noted, estimated coefficients are from Poisson regressions, standard errors (in parentheses) are corrected for clustering at the county-year level, and controls include 8 year indicators, 11 month indicators, 20 agency indicators, agency-specific linear time trends, the natural log of the agency population, and the county unemployment rate. Data on crime reports at the agency-month level are from the National Incident Based Reporting System and cover the period 2001-2009. 
Table 4. Troop Levels, Deployments, and Crime

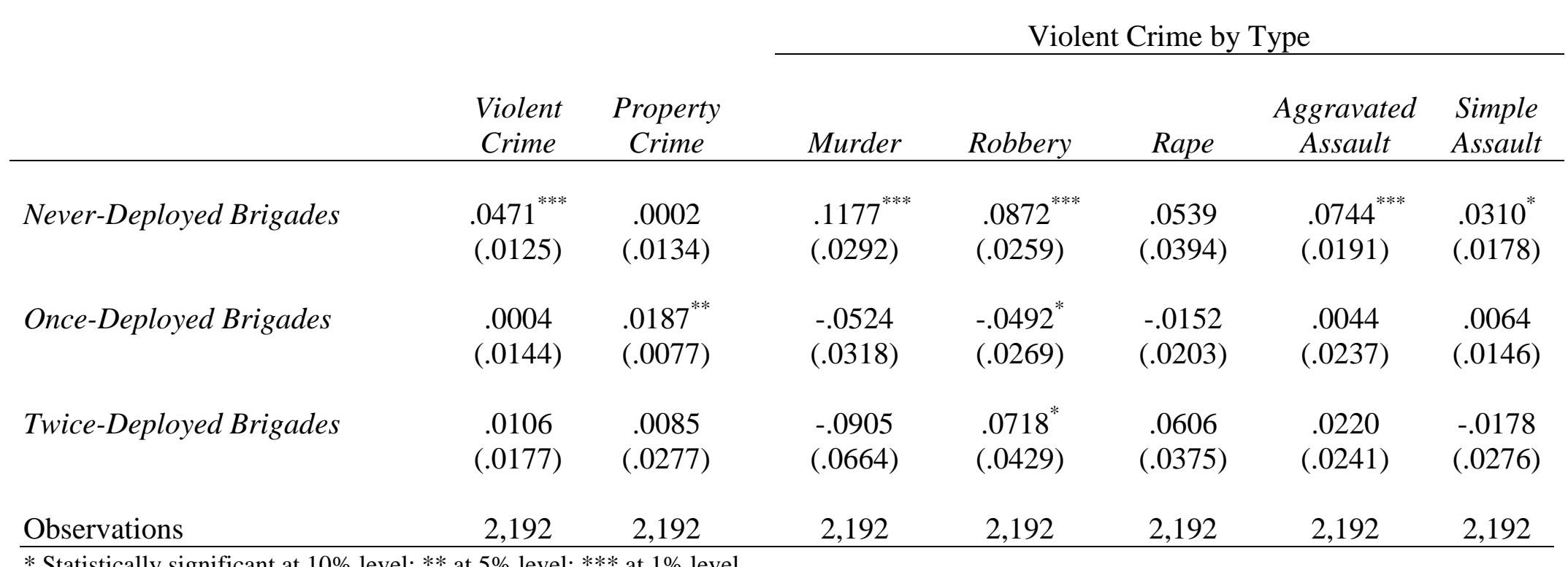

* Statistically significant at $10 \%$ level; ** at $5 \%$ level; *** at $1 \%$ level

Notes: The estimated relationship between combat brigades and murders is from an OLS regression. All other estimated coefficients are from Poisson regressions. Data on crime reports at the agency-month level are from the National Incident Based Reporting System and cover the period 2001-2009.

Property crimes include arson, burglary, larceny, motor vehicle theft, stolen property and vandalism. Controls include 8 year indicators, 11 month indicators, 20 agency indicators, agency-specific linear time trends, the natural log of the agency population, and the county unemployment rate. Standard errors (in parentheses) are corrected for clustering at the county-year level. 
Table 5. Troop Levels, Cumulative Fatalities, and Crime

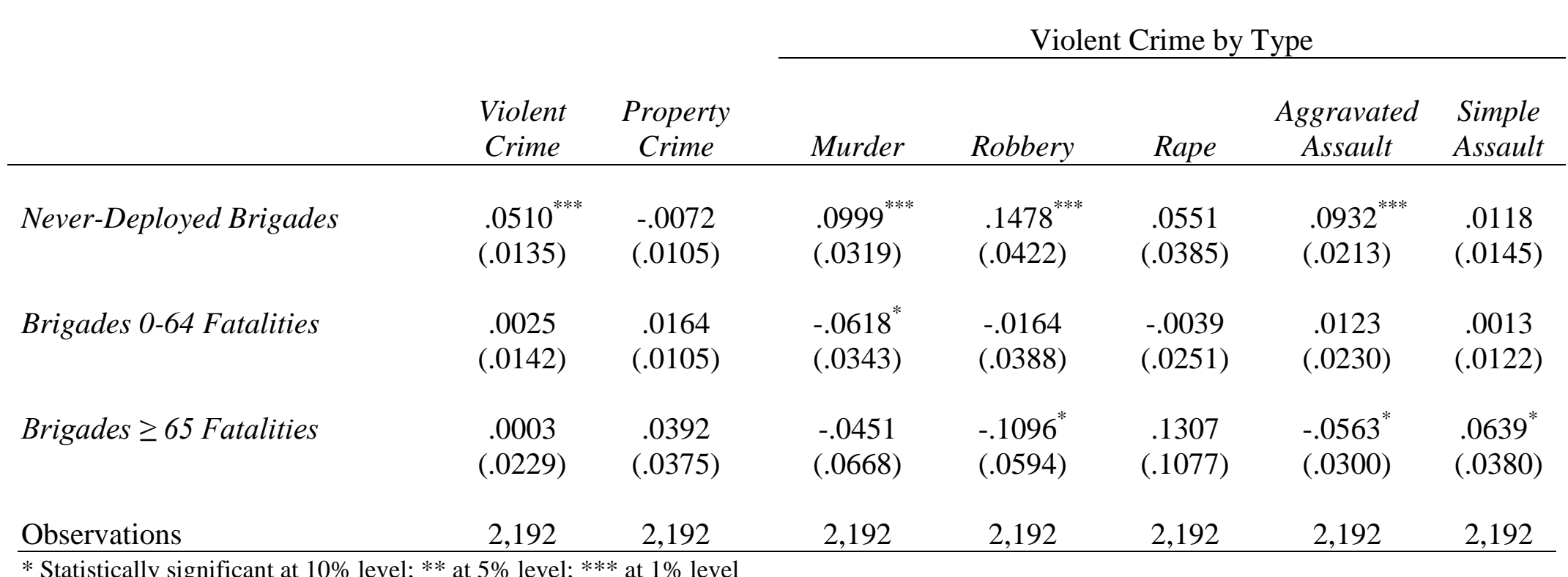

* Statistically significant at $10 \%$ level; ** at $5 \%$ level; *** at $1 \%$ level

Notes: The estimated relationship between combat brigades and murders is from an OLS regression. All other estimated coefficients are from Poisson regressions. Data on crime reports at the agency-month level are from the National Incident Based Reporting System and cover the period 2001-2009. Property crimes include arson, burglary, larceny, motor vehicle theft, stolen property and vandalism. Controls include 8 year indicators, 11 month indicators, 20 agency indicators, agency-specific linear time trends, the natural log of the agency population, and the county unemployment rate. Standard errors (in parentheses) are corrected for clustering at the county-year level. 
Table 6. Troop Levels, Deployment in the Past Year, and Crime

\begin{tabular}{|c|c|c|c|c|c|c|c|}
\hline & \multirow[b]{2}{*}{$\begin{array}{l}\text { Violent } \\
\text { Crime }\end{array}$} & \multirow[b]{2}{*}{$\begin{array}{c}\text { Property } \\
\text { Crime }\end{array}$} & \multicolumn{5}{|c|}{ Violent Crime by Type } \\
\hline & & & Murder & Robbery & Rape & $\begin{array}{c}\text { Aggravated } \\
\text { Assault }\end{array}$ & $\begin{array}{l}\text { Simple } \\
\text { Assault }\end{array}$ \\
\hline Brigades Not Deployed Past Year & $\begin{array}{l}.0383^{* * *} \\
(.0119)\end{array}$ & $\begin{array}{c}-.0042 \\
(.0098)\end{array}$ & $\begin{array}{l}.0630^{* *} \\
(.0301)\end{array}$ & $\begin{array}{l}.1116^{* * *} \\
(.0265)\end{array}$ & $\begin{array}{c}.0584 \\
(.0368)\end{array}$ & $\begin{array}{l}.0645^{* * *} \\
(.0183)\end{array}$ & $\begin{array}{l}.0100 \\
(.0145)\end{array}$ \\
\hline Brigades Returned Past Year & $\begin{array}{c}.0138 \\
(.0147)\end{array}$ & $\begin{array}{l}.0172^{*} \\
(.0103)\end{array}$ & $\begin{array}{l}-.0337 \\
(.0311)\end{array}$ & $\begin{array}{c}-.0006 \\
(.0299)\end{array}$ & $\begin{array}{c}.0212 \\
(.0263)\end{array}$ & $\begin{array}{c}.0199 \\
(.0198)\end{array}$ & $\begin{array}{l}.0155 \\
(.0130)\end{array}$ \\
\hline Observations & 2,192 & 2,192 & 2,192 & 2,192 & 2,192 & 2,192 & 2,192 \\
\hline
\end{tabular}

* Statistically significant at $10 \%$ level; ** at $5 \%$ level; *** at $1 \%$ level

Notes: The estimated relationship between combat brigades and murders is from an OLS regression. All other estimated coefficients are from Poisson regressions. Data on crime reports at the agency-month level are from the National Incident Based Reporting System and cover the period 2001-2009. Property crimes include arson, burglary, larceny, motor vehicle theft, stolen property and vandalism. Controls include 8 year indicators, 11 month indicators, 20 agency indicators, agency-specific linear time trends, the natural log of the agency population, and the county unemployment rate. Standard errors (in parentheses) are corrected for clustering at the county-year level. 
Table 7. Troop Levels, Fatalities Suffered During Last Deployment, and Crime

\begin{tabular}{|c|c|c|c|c|c|c|c|}
\hline & \multirow[b]{2}{*}{$\begin{array}{l}\text { Violent } \\
\text { Crime }\end{array}$} & \multirow[b]{2}{*}{$\begin{array}{c}\text { Property } \\
\text { Crime }\end{array}$} & \multicolumn{5}{|c|}{ Violent Crime by Type } \\
\hline & & & Murder & Robbery & Rape & $\begin{array}{c}\text { Aggravated } \\
\text { Assault }\end{array}$ & $\begin{array}{l}\text { Simple } \\
\text { Assault }\end{array}$ \\
\hline Never-Deployed Brigades & $\begin{array}{l}.0513^{* * *} \\
(.0132)\end{array}$ & $\begin{array}{l}-.0027 \\
(.0101)\end{array}$ & $\begin{array}{l}.1056^{* * *} \\
(.0273)\end{array}$ & $\begin{array}{l}.1439^{* * *} \\
(.0386)\end{array}$ & $\begin{array}{c}.0817^{*} \\
(.0421)\end{array}$ & $\begin{array}{l}.0845^{* * *} \\
(.0190)\end{array}$ & $\begin{array}{c}.0177 \\
(.0140)\end{array}$ \\
\hline Brigades 0-16 Fatalities & $\begin{array}{l}-.0004 \\
(.0105)\end{array}$ & $\begin{array}{c}.0137 \\
(.0117)\end{array}$ & $\begin{array}{l}-.0717 \\
(.0470)\end{array}$ & $\begin{array}{l}-.0727^{* *} \\
(.0342)\end{array}$ & $\begin{array}{c}.0042 \\
(.0223)\end{array}$ & $\begin{array}{l}-.0104 \\
(.0180)\end{array}$ & $\begin{array}{l}.0274^{* *} \\
(.0122)\end{array}$ \\
\hline Brigades $\geq 17$ Fatalities & $\begin{array}{c}.0054 \\
(.0201)\end{array}$ & $\begin{array}{c}.0200 \\
(.0123)\end{array}$ & $\begin{array}{l}-.0478 \\
(.0443)\end{array}$ & $\begin{array}{c}.0364 \\
(.0488)\end{array}$ & $\begin{array}{c}.0013 \\
(.0316)\end{array}$ & $\begin{array}{c}.0271 \\
(.0288)\end{array}$ & $\begin{array}{l}-.0222 \\
(.0170)\end{array}$ \\
\hline Observations & 2,192 & 2,192 & 2,192 & 2,192 & 2,192 & 2,192 & 2,192 \\
\hline
\end{tabular}

Notes: The estimated relationship between combat brigades and murders is from an OLS regression. All other estimated coefficients are from Poisson regressions. Data on crime reports at the agency-month level are from the National Incident Based Reporting System and cover the period 2001-2009. Property crimes include arson, burglary, larceny, motor vehicle theft, stolen property and vandalism. Controls include 8 year indicators, 11 month indicators, 20 agency indicators, agency-specific linear time trends, the natural log of the agency population, and the county unemployment rate. Standard errors (in parentheses) are corrected for clustering at the county-year level. 
Table 8. Troop Levels and Arrests

\begin{tabular}{|c|c|c|c|}
\hline & \multicolumn{3}{|c|}{ Arrests of Males for Violent Crime } \\
\hline & 18-29 year-olds & 30-39 year-olds & $40+$ year-olds \\
\hline Brigades & $\begin{array}{l}.0281^{*} \\
(.0152)\end{array}$ & $\begin{array}{c}.0276 \\
(.0177)\end{array}$ & $\begin{array}{l}-.0070 \\
(.0150)\end{array}$ \\
\hline $\begin{array}{l}\text { Mean dep. variable, } \\
\text { all agencies }\end{array}$ & 11.02 & 6.374 & 5.716 \\
\hline $\begin{array}{l}\text { Mean dep. variable, } \\
\text { Colorado Springs } \\
\text { Police Department }\end{array}$ & 69.93 & 34.11 & 30.15 \\
\hline $\begin{array}{l}\text { Mean dep. variable, } \\
\text { El Paso County } \\
\text { Sheriff's Office }\end{array}$ & 14.96 & 7.375 & 8.333 \\
\hline Observations & 1,669 & 1,635 & 1,627 \\
\hline
\end{tabular}

* Statistically significant at $10 \%$ level; ** at $5 \%$ level; *** at $1 \%$ level

Notes: All estimated coefficients are from Poisson regressions. Data on arrests at the agency-month level are from the National Incident Based Reporting System and cover the period 2001-2007. Controls include 6 year indicators, 11 month indicators, 20 agency indicators, agency-specific linear time trends, the natural log of the agency population, and the county unemployment rate. Standard errors (in parentheses) are corrected for clustering at the county-year level. 
Table 9. Troop Levels, Deployments, and Arrests

\section{Arrests of Males for Violent Crime}

18-29 year olds $\quad 30-39$ year olds $\quad 40+$ year olds

\begin{tabular}{lccc} 
Never-Deployed Brigades & $.0526^{* * *}$ & .0278 & -.0091 \\
& $(.0180)$ & $(.0261)$ & $(.0189)$ \\
Deployed Brigades & .0067 & .0275 & -.0053 \\
& $(.0176)$ & $(.0195)$ & $(.0215)$ \\
Observations & 1,669 & 1,635 & 1,627 \\
\hline
\end{tabular}

* Statistically significant at $10 \%$ level; ** at $5 \%$ level; *** at $1 \%$ level

Notes: All estimated coefficients are from Poisson regressions. Data on arrests at the agency-month level are from the National Incident Based Reporting System and cover the period 2001-2007. Controls include 6 year indicators, 11 month indicators, 20 agency indicators, agency-specific linear time trends, the natural log of the agency population, and the county unemployment rate. Standard errors (in parentheses) are corrected for clustering at the county-year level. 
Table 10. Police Officers and Troop Levels

\begin{tabular}{|c|c|c|c|c|c|c|}
\hline & $\begin{array}{l}\text { Sworn } \\
\text { Officers }\end{array}$ & $\begin{array}{l}\text { Sworn } \\
\text { Officers }\end{array}$ & $\begin{array}{l}\text { Sworn } \\
\text { Officers }\end{array}$ & $\begin{array}{l}\text { Sworn } \\
\text { Officers }\end{array}$ & $\begin{array}{l}\text { Sworn } \\
\text { Officers }\end{array}$ & $\begin{array}{l}\text { Sworn } \\
\text { Officers }\end{array}$ \\
\hline Average Brigades & $\begin{array}{l}-.0414 \\
(.0519)\end{array}$ & $\begin{array}{l}-.0212 \\
(.0270)\end{array}$ & $\ldots$ & $\ldots$ & $\ldots$ & $\cdots$ \\
\hline $\begin{array}{l}\text { Average Never-Deployed } \\
\text { Brigades }\end{array}$ & $\ldots$ & $\ldots$ & $\begin{array}{l}-.0462 \\
(.0335)\end{array}$ & $\begin{array}{l}-.0103 \\
(.0338)\end{array}$ & $\begin{array}{l}-.0462 \\
(.0338)\end{array}$ & $\begin{array}{l}-.0499 \\
(.0302)\end{array}$ \\
\hline $\begin{array}{l}\text { Average Once-Deployed } \\
\text { Brigades }\end{array}$ & $\cdots$ & $\cdots$ & $\begin{array}{c}.0276 \\
(.0400)\end{array}$ & $\begin{array}{l}.0356^{*} \\
(.0210)\end{array}$ & $\cdots$ & $\cdots$ \\
\hline $\begin{array}{l}\text { Average Twice-Deployed } \\
\text { Brigades }\end{array}$ & $\ldots$ & $\ldots$ & $\begin{array}{l}-.0078 \\
(.0456)\end{array}$ & $\begin{array}{l}-.0462 \\
(.0579)\end{array}$ & $\ldots$ & $\ldots$ \\
\hline $\begin{array}{l}\text { Average Brigades 0-64 } \\
\text { Fatalities }\end{array}$ & ... & ... & $\ldots$ & $\ldots$ & $\begin{array}{l}.0183 \\
(.0414)\end{array}$ & $\begin{array}{c}.0329 \\
(.0272)\end{array}$ \\
\hline $\begin{array}{l}\text { Average Brigades } \geq 65 \\
\text { Fatalities }\end{array}$ & $\ldots$ & $\ldots$ & $\ldots$ & $\ldots$ & $\begin{array}{l}-.0320 \\
(.0643)\end{array}$ & $\begin{array}{c}.0619 \\
(.0678)\end{array}$ \\
\hline Observations & 175 & 175 & 175 & 175 & 175 & 175 \\
\hline $\begin{array}{l}\text { Agency-specific } \\
\text { linear time trends } \\
\end{array}$ & No & Yes & No & Yes & No & Yes \\
\hline \multicolumn{7}{|c|}{ * Statistically significant at $10 \%$ level; $* *$ at $5 \%$ level; $* * *$ at $1 \%$ level } \\
\hline $\begin{array}{l}\text { Notes: All estimated coefficient } \\
\text { the Uniform Crime Reporting } P \\
\text { the number of sworn officers in } \\
\text { indicators, and lags of the coun } \\
\text { the county-year level. }\end{array}$ & $\begin{array}{l}\text { from OLS } \\
\text { am and cove } \\
\text { gency per } 1 \\
\text { lemploymen }\end{array}$ & $\begin{array}{l}\text { egressions. } \\
\text { the period } \\
0,000 \text { popu } \\
\text { rate. Stand }\end{array}$ & $\begin{array}{l}\text { on sworn } \\
1-2009 . \text { Th }\end{array}$ & $\begin{array}{l}\text { fficers at th } \\
\text { dependent } \\
\text { include } 8 \text { y } \\
\text { rentheses) a }\end{array}$ & $\begin{array}{l}\text { ency-year le } \\
\text { able is the na } \\
\text { adicators, } 20 \\
\text { rrected for }\end{array}$ & $\begin{array}{l}\text { el are from } \\
\text { agencl log of } \\
\text { lustering at }\end{array}$ \\
\hline
\end{tabular}




\section{Appendix A. Figures and Tables}

Appendix Figure A1. Variation in Never-Deployed Brigades, Once-Deployed Brigades, and Twice-Deployed Brigades, 2001-2009
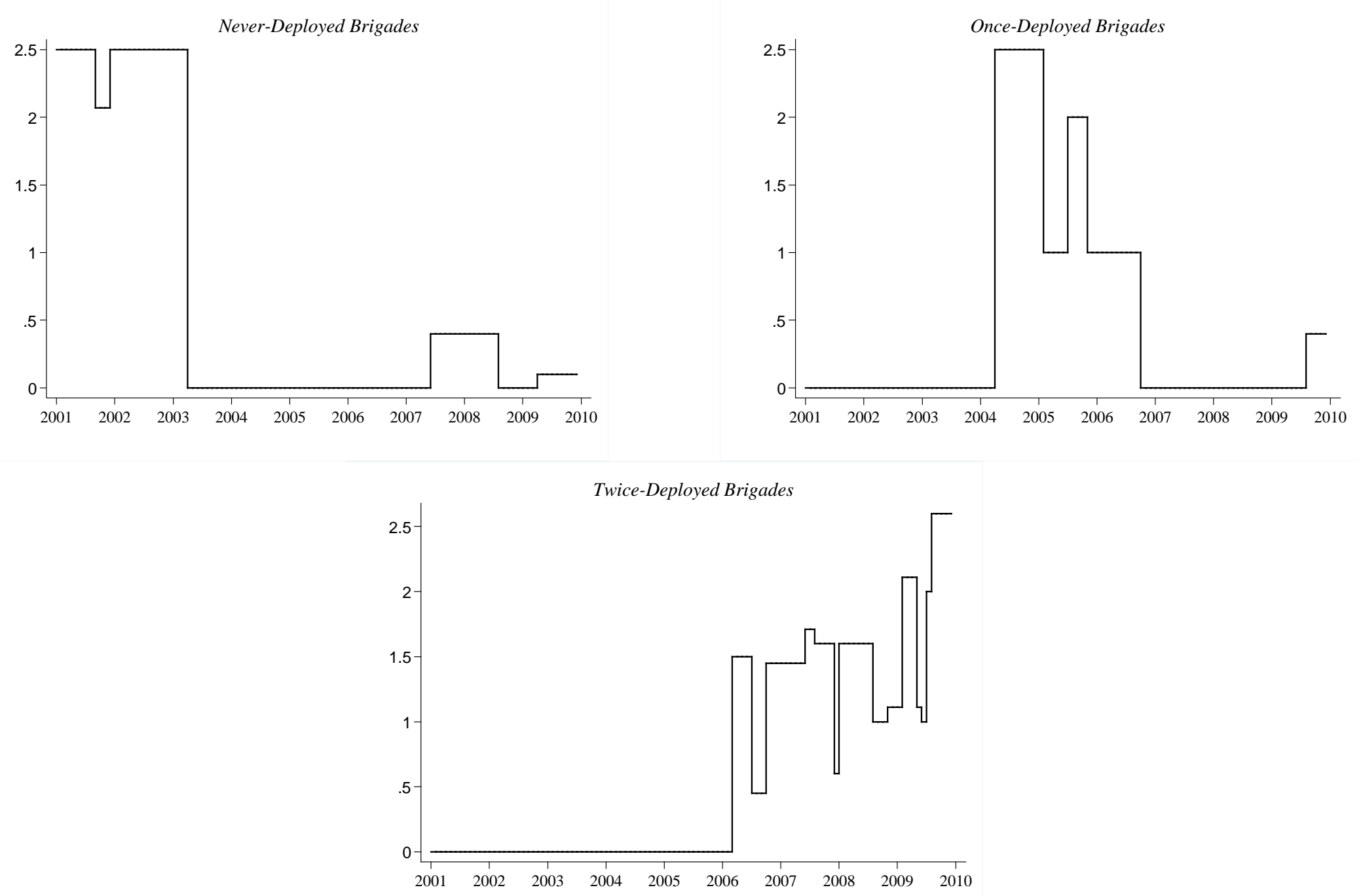
Appendix Figure A2. Variation in Brigades 0-64 Fatalities and Brigades $\geq 65$ Fatalities, 2001-2009

Brigades 0-64 Fatalities
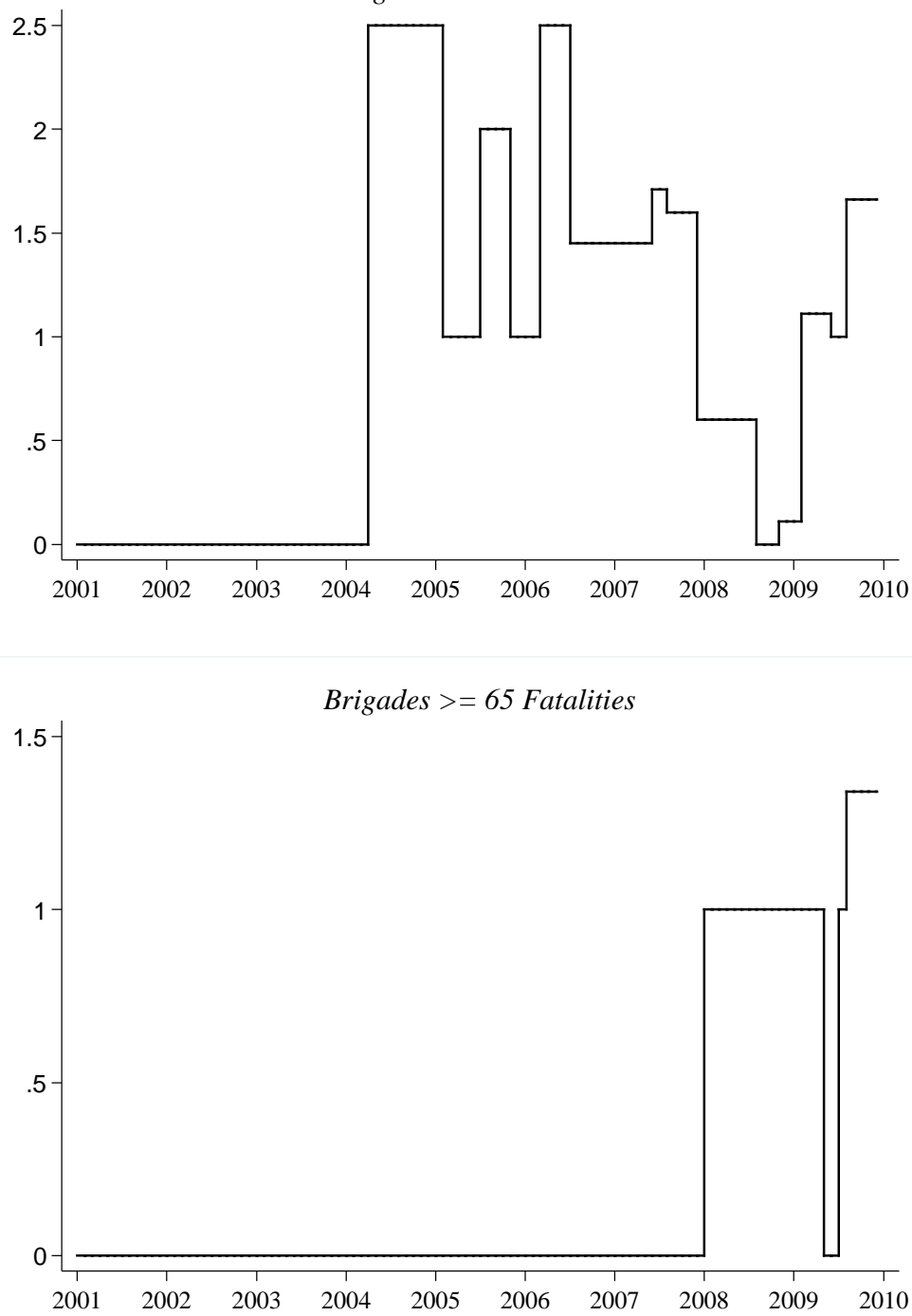
Appendix Figure A3. Variation in Brigades Not Deployed Past Year and Brigades Returned Past Year, 2001-2009
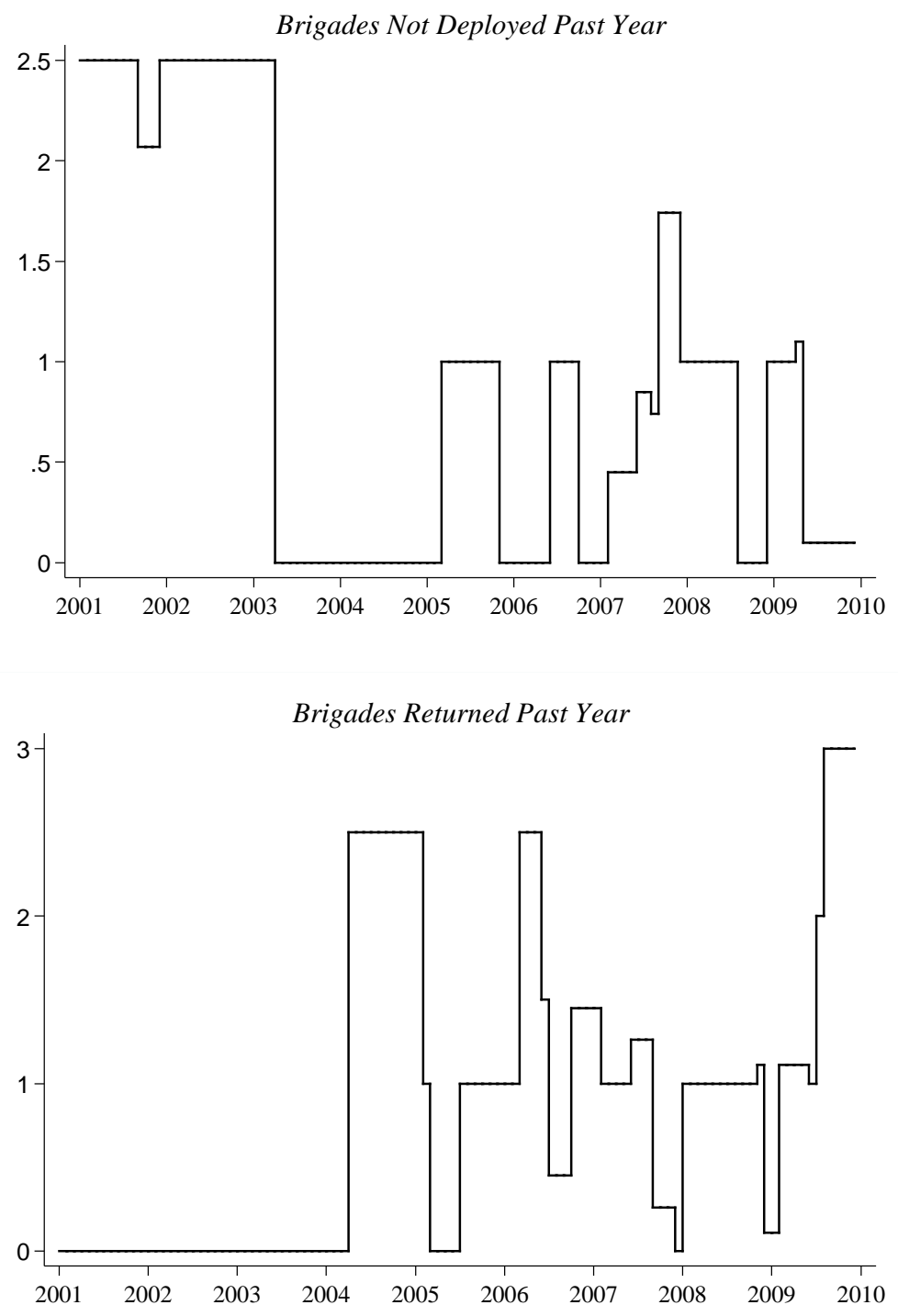
Appendix Figure A4. Variation in Brigades 0-16 Fatalities, and Brigades $\geq 17$ Fatalities, 2001-2009
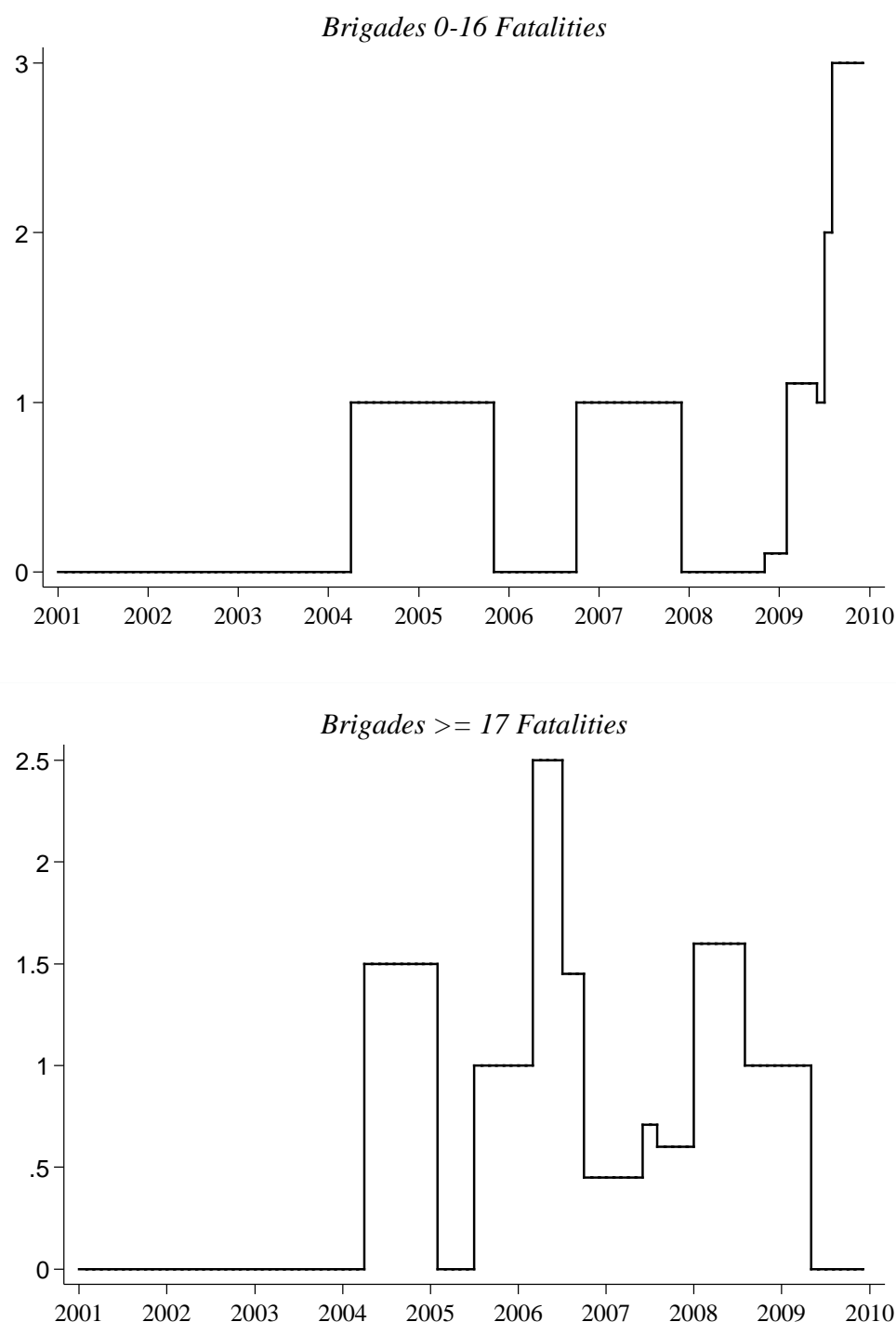
Appendix Figure A5. Variation in Never-Deployed Brigades and Deployed Brigades at Fort Carson, 2001-2007
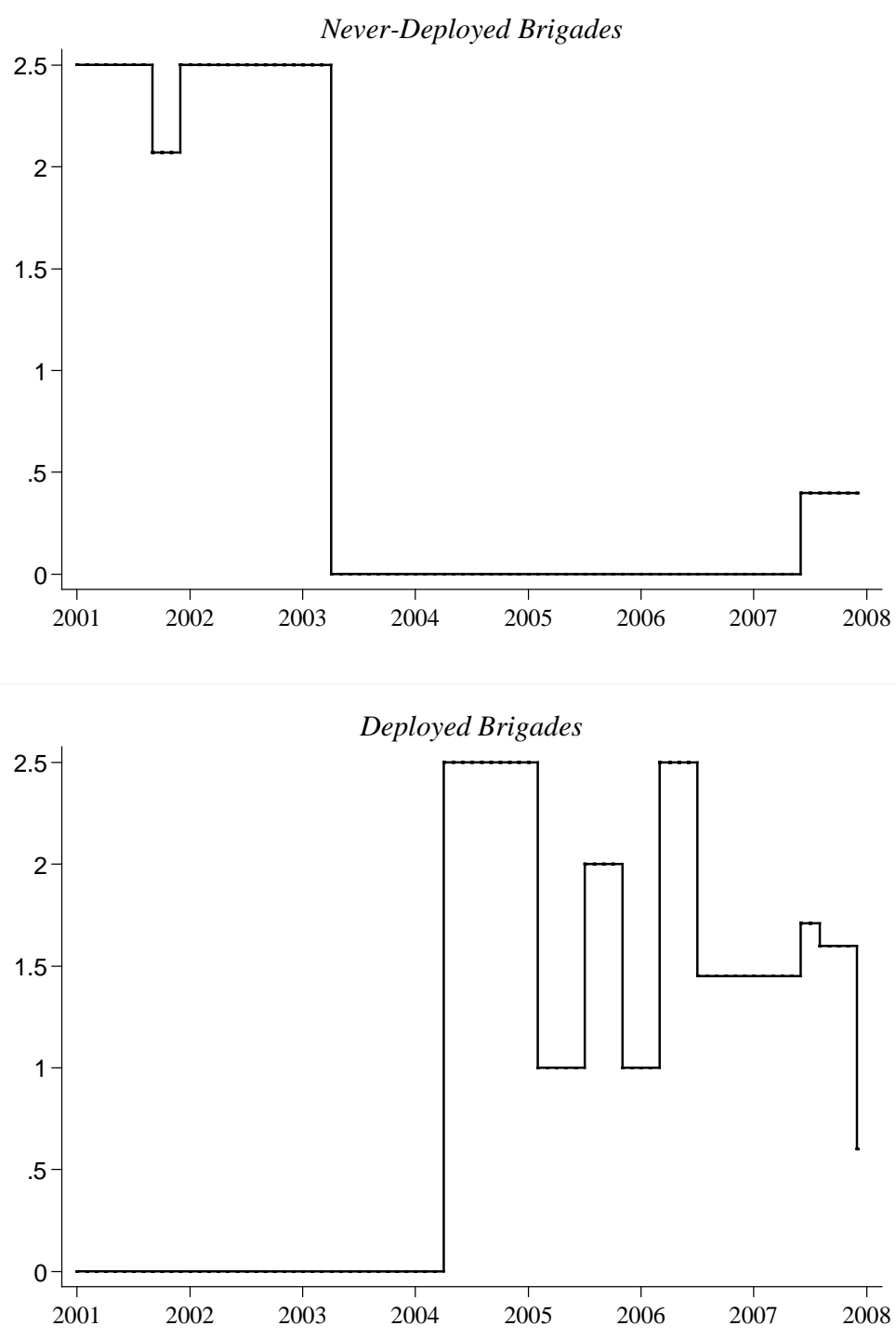


\section{Appendix Table A1. Descriptive Statistics for Independent Variables}

\begin{tabular}{lcc} 
Variable & Mean (SD) & Description \\
Brigades & $.1468(.5429)$ & Number of combat brigades at Fort Carson \\
Population & $10.50(1.396)$ & Natural logarithm of agency population \\
Unemployment & $5.257(1.457)$ & County unemployment rate \\
\hline
\end{tabular}

Notes: Sources used to construct the variable Brigades are given in Appendix B. Agency-level population data are provided by the NIBRS. Unemployment data come from the Bureau of Labor Statistics and are available at: http://www.bls.gov/lau/. 
Appendix Table A2. Unemployment as a Predictor of Troop Levels at Ft. Carson

\begin{tabular}{|c|c|c|c|c|c|}
\hline & Brigades & Brigades & Brigades & Brigades & Brigades \\
\hline Unemployment rate (1 month lag) & $\begin{array}{c}.0005 \\
(.0197)\end{array}$ & $\begin{array}{c}-.0238 \\
(.0384)\end{array}$ & $\begin{array}{c}-.0199 \\
(.0329)\end{array}$ & $\begin{array}{l}-.0103 \\
(.0293)\end{array}$ & $\begin{array}{l}-.0037 \\
(.0297)\end{array}$ \\
\hline Unemployment rate (2 month lag) & .. & $\begin{array}{c}.0259 \\
(.0478)\end{array}$ & $\begin{array}{c}.0101 \\
(.0277)\end{array}$ & $\begin{array}{c}.0073 \\
(.0276)\end{array}$ & $\begin{array}{c}.0090 \\
(.0279)\end{array}$ \\
\hline Unemployment rate (3 month lag) & $\ldots$ & $\ldots$ & $\begin{array}{c}.0133 \\
(.0321)\end{array}$ & $\begin{array}{c}-.0233 \\
(.0264)\end{array}$ & $\begin{array}{c}-.0253 \\
(.0277)\end{array}$ \\
\hline Unemployment rate (4 month lag) & $\cdots$ & $\cdots$ & $\ldots$ & $\begin{array}{c}.0320 \\
(.0389)\end{array}$ & $\begin{array}{c}.0001 \\
(.0206)\end{array}$ \\
\hline Unemployment rate (5 month lag) & $\cdots$ & $\ldots$ & $\ldots$ & $\cdots$ & $\begin{array}{c}.0292 \\
(.0440)\end{array}$ \\
\hline Observations & 2,192 & 2,192 & 2,192 & 2,192 & 2,192 \\
\hline
\end{tabular}

Notes: OLS estimates of the relationship between the (lagged) unemployment rate and the number of combat brigades at Fort Carson are reported. Controls include 8 year indicators, 11 month indicators, 20 agency indicators, and the natural log of the agency population. Standard errors (in parentheses) are corrected for clustering at the county-year level. 
Appendix Table A3. Troop Levels, Deployment in the Past 3 Months, and Crime

\begin{tabular}{|c|c|c|c|c|c|c|c|}
\hline & \multirow[b]{2}{*}{$\begin{array}{l}\text { Violent } \\
\text { Crime }\end{array}$} & \multirow[b]{2}{*}{$\begin{array}{l}\text { Property } \\
\text { Crime }\end{array}$} & \multicolumn{5}{|c|}{ Violent Crime by Type } \\
\hline & & & Murder & Robbery & Rape & $\begin{array}{c}\text { Aggravated } \\
\text { Assault }\end{array}$ & $\begin{array}{l}\text { Simple } \\
\text { Assault }\end{array}$ \\
\hline $\begin{array}{l}\text { Brigades Not Deployed Past } 3 \\
\text { Months }\end{array}$ & $\begin{array}{l}.0249^{* *} \\
(.0116)\end{array}$ & $\begin{array}{c}.0087 \\
(.0053)\end{array}$ & $\begin{array}{r}-.0017 \\
(.0379)\end{array}$ & $\begin{array}{l}.0521^{* *} \\
(.0216)\end{array}$ & $\begin{array}{l}.0345 \\
(.0293)\end{array}$ & $\begin{array}{l}.0350^{* *} \\
(.0174)\end{array}$ & $\begin{array}{l}.0135 \\
(.0108)\end{array}$ \\
\hline Brigades Returned Past 3 Months & $\begin{array}{c}.0223 \\
(.0163)\end{array}$ & $\begin{array}{c}.0011 \\
(.0175)\end{array}$ & $\begin{array}{c}.0040 \\
(.0392)\end{array}$ & $\begin{array}{c}.0263 \\
(.0286)\end{array}$ & $\begin{array}{l}.0419 \\
(.0382)\end{array}$ & $\begin{array}{l}.0416^{* *} \\
(.0164)\end{array}$ & $\begin{array}{l}.0081 \\
(.0192)\end{array}$ \\
\hline Observations & 2,192 & 2,192 & 2,192 & 2,192 & 2,192 & 2,192 & 2,192 \\
\hline
\end{tabular}

* Statistically significant at $10 \%$ level; ** at $5 \%$ level; *** at $1 \%$ level

Notes: The estimated relationship between combat brigades and murders is from an OLS regression. All other estimated coefficients are from Poisson regressions. Data on crime reports at the agency-month level are from the National Incident Based Reporting System and cover the period 2001-2009. Property crimes include arson, burglary, larceny, motor vehicle theft, stolen property and vandalism. Controls include 8 year indicators, 11 month indicators, 20 agency indicators, agency-specific linear time trends, the natural log of the agency population, and the county unemployment rate. Standard errors (in parentheses) are corrected for clustering at the county-year level. 
Appendix Table A4. Troop Levels, Deployment in the Past 6 Months, and Crime

\begin{tabular}{|c|c|c|c|c|c|c|c|}
\hline & \multirow[b]{2}{*}{$\begin{array}{l}\text { Violent } \\
\text { Crime }\end{array}$} & \multirow[b]{2}{*}{$\begin{array}{l}\text { Property } \\
\text { Crime }\end{array}$} & \multicolumn{5}{|c|}{ Violent Crime by Type } \\
\hline & & & Murder & Robbery & Rape & $\begin{array}{c}\text { Aggravated } \\
\text { Assault }\end{array}$ & $\begin{array}{l}\text { Simple } \\
\text { Assault }\end{array}$ \\
\hline $\begin{array}{l}\text { Brigades Not Deployed Past } 6 \\
\text { Months }\end{array}$ & $\begin{array}{l}.0295^{* * *} \\
(.0102)\end{array}$ & $\begin{array}{c}.0074 \\
(.0060)\end{array}$ & $\begin{array}{r}.0217 \\
(.0307)\end{array}$ & $\begin{array}{l}.0615^{* * *} \\
(.0195)\end{array}$ & $\begin{array}{l}.0319 \\
(.0307)\end{array}$ & $\begin{array}{l}.0442^{* * *} \\
(.0141)\end{array}$ & $\begin{array}{c}.0159 \\
(.0110)\end{array}$ \\
\hline Brigades Returned Past 6 Months & $\begin{array}{c}.0134 \\
(.0165)\end{array}$ & $\begin{array}{c}.0083 \\
(.0094)\end{array}$ & $\begin{array}{l}-.0402 \\
(.0494)\end{array}$ & $\begin{array}{c}.0183 \\
(.0311)\end{array}$ & $\begin{array}{l}.0429 \\
(.0336)\end{array}$ & $\begin{array}{l}.0212 \\
(.0267)\end{array}$ & $\begin{array}{c}.0050 \\
(.0162)\end{array}$ \\
\hline Observations & 2,192 & 2,192 & 2,192 & 2,192 & 2,192 & 2,192 & 2,192 \\
\hline
\end{tabular}

* Statistically significant at $10 \%$ level; ** at $5 \%$ level; *** at $1 \%$ level

Notes: The estimated relationship between combat brigades and murders is from an OLS regression. All other estimated coefficients are from Poisson regressions. Data on crime reports at the agency-month level are from the National Incident Based Reporting System and cover the period 2001-2009. Property crimes include arson, burglary, larceny, motor vehicle theft, stolen property and vandalism. Controls include 8 year indicators, 11 month indicators, 20 agency indicators, agency-specific linear time trends, the natural log of the agency population, and the county unemployment rate. Standard errors (in parentheses) are corrected for clustering at the county-year level. 


\title{
Appendix Table A5. Troop Levels, Cumulative Fatalities, and Arrests
}

\author{
Arrests of Males for Violent Crime
}

18-29 year olds

30-39 year olds

$40+$ year olds

Never-Deployed Brigades

$.0504^{* * *}$

.0273

$-.0057$

(.0258)

(.0176)

Brigades 0-51 Fatalities

$-.0005$

.0260

.0047

(.0163)

(.0158)

Brigades $\geq 52$ Fatalities

.0302

.0326

$-.0411$

(.0214)

(.0373)

(.0269)

Observations

1,669

1,635

1,627

* Statistically significant at $10 \%$ level; ** at $5 \%$ level; *** at $1 \%$ level

Notes: All estimated coefficients are from Poisson regressions. Data on arrests at the agency-month level are from the National Incident Based Reporting System and cover the period 2001-2007. Controls include 6 year indicators, 11 month indicators, 20 agency indicators, agency-specific linear time trends, the natural log of the agency population, and the county unemployment rate. Standard errors (in parentheses) are corrected for clustering at the county-year level. 


\section{Appendix Table A6. Arrests of Females 18+ Years of Age}

\section{Arrests of Females for Violent Crime}

Brigades $\quad .0015$

(.0101)

Never-Deployed Brigades

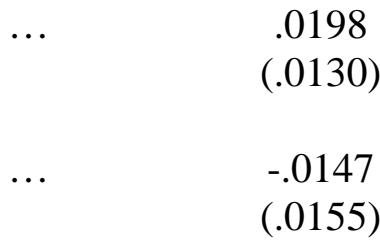

.0202

$(.0127)$

Deployed Brigades

$(.0155)$

Brigades 0-49 Fatalities

$\cdots \quad \ldots$

Brigades $\geq 50$ Fatalities

-. $\quad$.

$-.0182$

(.0224)

Observations

1,639

1,639

1,639

* Statistically significant at $10 \%$ level; ** at $5 \%$ level; *** at $1 \%$ level

Notes: All estimated coefficients are from Poisson regressions. Data on arrests at the agency-month level are from the National Incident Based Reporting System and cover the period 2001-2007.

Controls include 6 year indicators, 11 month indicators, 20 agency indicators, agency-specific linear time trends, the natural log of the agency population, and the county unemployment rate. Standard errors (in parentheses) are corrected for clustering at the county-year level. 


\section{Appendix B. Combat Units Assigned to Fort Carson, 2001-2009}

The $1^{\text {st }}$ Brigade $4^{\text {th }}$ Infantry Division (1BCT 4ID), also known as “The Raiders", moved from Ft. Hood to Ft. Carson in July 2009. This move, announced in 2007, was in accordance with the recommendations of the 2005 BRAC Commission.

Deployments to Iraq:

March 2003-April 2004 (9 fatalities)

December 2005-December 2006 (50 fatalities)

March 2008-March 2009 (13 fatalities)

\section{Sources:}

Badger, T.A. 2005. “4th Infantry Deployment Ramping up at Fort Hood.” Associated Press, November 30.

Available at: http://www.freerepublic.com/focus/f-news/1533870/posts

Baker, Emily 2006. "Final Flight of 4th Infantry Troops Returns to Fort Hood.” Killeen Daily Herald, December 20. Available at: http://kdhnews.com/news/texas/final-flight-of-th-infantry-troops-returns-to-fort-

hood/article_bf08a71c-aa6f-53fb-a033-87c18098575a.htm

Cummings, Tam. 2004. "Fort Hood Hosts Texas-Size Homecoming Celebration.” American Forces Press Service, April 23. Available at: http://www.defense.gov/News/NewsArticle.aspx?ID=26822

Dwyer, Kevin J. 2003. “More Goodbyes, More Tears: About 1,000 Soldiers Say Farewell to their Families.” Killeen Daily Herald, March 29. Available at: http://a-1-8.org/Docs/activeunit/3-29news.html

Ingram, Andrew. 2009. “4th Inf. Div. Uncases Colors at Fort Carson.” Fort Carson Mountaineer, Vol. 67 No. 30 , p. 20 .

Fisher, Devon. 2009. “1st BCT, 4th ID Returns to Carson.” CSMNG.com, May 8. Available at: http://csmng.com/2009/05/08/1st-bct-4th-id-returns-to-carson/

Hodge, David. 2008. “Raider Brigade Soldiers Take Up Camp in Kuwait.” dvidshub.net, March 26. Available at: http://www.dvidshub.net/news/17771/raider-brigade-soldiers-take-up-camp-kuwait\#.Ue2NzfLna70

Pye, Breanne. 2010. “Raiders’ Case Colors.” Fort Carson Mountaineer, Vol. 68, No. 29, p. 1.

Klein, Philip. 2009. “Hood Bids 4th Inf. Div. Farewell.” Fort Carson Mountaineer, Vol. 67, No. 29 , p. 1.

Lorge, Elizabeth M. 2007. “Army Announces Stationing Decisions for New Troops.” Army News Service, Dec.

19. Available at: http://www.army.mil/article/6683/

Searcey, Dionne. 2003. “Preparing for Battle Thousands from 4th Division Deployed to Gulf.” Newsday, March 28. Available at: http://a-1-8.org/Docs/activeunit/3-28news.html

Staff Report. 2009. “More 4th ID Soldiers Arriving Home from Iraq.” Army Times, March 12. Available at: http://www.armytimes.com/article/20090312/NEWS/903120333/More-4th-ID-soldiers-arriving-home-from-Iraq 
The $2^{\text {nd }}$ Brigade $4^{\text {th }}$ Infantry (2BCT 4ID), also known as the "Warhorse Brigade", moved from Ft. Hood to Ft. Carson in June 2007. This move was based on the recommendations of the 2005 BRAC Commission and involved approximately 900 soldiers from Ft. Hood and 400 soldiers from other bases.

Deployments to Iraq:

March 2003-April 2004 (10 fatalities)

December 2005-December 2006 (39 fatalities)

August 2008-August 2009 (9 fatalities)

\section{Sources:}

Associated Press. 2006. “4th Infantry Troops Start Coming Home.” Laredo Morning Times, September 6. Available at: http://airwolf.lmtonline.com/news/archive/090606/pagea7.pdf

Baker, Emily 2006. "Final Flight of 4th Infantry Troops Returns to Fort Hood.” The Killeen Daily Herald, December 20. Available at: http://kdhnews.com/news/texas/final-flight-of-th-infantry-troops-returns-to-forthood/article_bf08a71c-aa6f-53fb-a033-87c18098575a.htm

Cavallaro, Gina. 2007. “4th ID Brigade Deployment Delayed.” Army Times, Oct. 25. Available at: http://www.armytimes.com/article/20071025/NEWS/710250327/4th-ID-Brigade-

Cummings, Tam. 2004. "Fort Hood Hosts Texas-Size Homecoming Celebration.” American Forces Press Service, April 23. Available at: http://www.defense.gov/News/NewsArticle.aspx?ID=26822

Dwyer, Kevin J. 2003. "More Goodbyes, More Tears: About 1,000 Soldiers Say Farewell to their Families.” Killeen Daily Herald, March 29. Available at: http://a-1-8.org/Docs/activeunit/3-29news.html

Foliente, Rodney, 2008. “Warhorse Brigade Cases Colors for Iraq Deployment.” Blackanthem Military News, Aug 25. Available at: http://www.blackanthem.com/News/Military_News_1/Warhorse-Brigade-cases-colors-for-Iraqdeployment18374.shtml

Ingram, Andrew. 2009. “2nd BCT Soldiers Return to Carson.” Fort Carson Mountaineer, Vol. 67, No. 31, p. 1.

Klein, Philip. 2009. “Warhorse Soldiers Come Home.” Fort Carson Mountaineer, Vol. 67, No. 30, p. 1.

Rappold, Scott. 2007. "Fort Hood Brigade Says it’s Glad to be Back at Carson.” Colorado Springs Gazette, June 30. Available at: http://gazette.com/fort-hood-brigade-says-its-glad-to-be-back-at-carson/article/24272

Ulibarri, Sarah 2001. “'Warhorse’ Ready for Afghanistan.” Army.mil, May 19. Available at: http://www.army.mil/article/56822/warhorse-ready-for-afghanistan/ 
The $3^{\text {rd }}$ Brigade $4{ }^{\text {th }}$ Infantry (3BCT 4ID), also known as the "Iron Brigade", was based at Ft. Carson during the period 2001-2009.

Deployments to Iraq:

April 2003-April 2004 (4 fatalities)

November 2005-October 2006 (16 fatalities)

December 2007-February 2009 (15 fatalities)

\section{Sources:}

Diedrich, John. 2003. "From Friendly Skies to Hostile Ground: Local Soldiers Fly Commercial to War.” Colorado Springs Gazette, March 28. Available at: http://a-1-8.org/Docs/activeunit/deploy.html

Fisher, Devin. 2009. “3rd BCT, 4th ID Soldiers Return in Waves.” Fort Carson Mountaineer, Vol. 67 No. 7, p. 20.

Harris, Paul J. 2007. “Strikers Leave for another Deployment to Iraq.”The Fort Carson Mountaineer, Vol. 65, No. 49, p. 1.

Jewell, Lorie. 2004. “Across America, Soldiers Arrive Home to Rousing Welcomes.” Army News, April 16. Available at://www.freerepublic.com/focus/f-news/1119221/posts

Roeder, Tom. 2013. “Iraq: Ten Years Later.” Colorado Springs Gazette, March 15. Available at: http://gazette.com/iraq-ten-years-later/article/152318

Stein, Clint. 2005. “3rd HBCT Off to OIF Again” Fort Carson Mountaineer, Vol. 63, No. 48, p. 1.

Tonn, Rebecca E. 2006. “Home at Last.” Fort Carson Mountaineer, Vol.63, No 49, p. 1. 
The $2{ }^{\text {nd }}$ Brigade $2^{\text {nd }}$ Infantry Division (2BCT 2ID), also known as the "Warrior Brigade", was originally based in S. Korea. It was deployed to Iraq in August 2004 and was redeployed to Ft. Carson in July 2005. The redeployment of the 2BCT 2ID was initially described as a temporary relocation, but was made permanent based on the recommendations of the 2005

BRAC Commission. Its name was changed to the $4^{\text {th }}$ Brigade $4^{\text {th }}$ Infantry (4BCT 4ID) on April 8, 2008 (i.e., it was reflagged). It was deployed to Afghanistan in May of 2009.

Deployments to Iraq:

August 2004-July 2005(53 fatalities)

October 2006-January 2008 (43 fatalities)

\section{Sources:}

Associated Press. 2008. "More Fort Carson Soldiers Return from Iraq.” Denver Post, January 1. Available at: http://www.denverpost.com/ci_7856572?source=bb

Cushing, Eugene H. 2009. “4th BCT Ready to Deploy.” Fort Carson Mountaineer, Vol. 67 No. 18, p. 5.

Kretsinger, Stephen. 2005. “Mountain Post Welcomes 2nd BCT.” Fort Carson Mountaineer, Vol. 63, No. 31, p. 3.

Marulli, Courtney E. 2008. “Unit Changes Name, History.” Fort Carson Mountaineer, Vol. 66, No. 16 , p. 1.

Robson, Seth. 2004. “After Iraq, 2nd BCT will Call Fort Carson Home.” Stars and Stripes, September 26. Available at: http://www.stripes.com/news/after-iraq-2nd-bct-will-call-fort-carson-home-1.24504

Roeder, Tom. 2013. “Iraq: Ten Years Later.” Colorado Springs Gazette, March 15. Available at: http://gazette.com/iraq-ten-years-later/article/152318

Smith, Chris. 2005. “SMA Welcomes Home 2nd BCT.” Fort Carson Mountaineer, Vol. 63, No. 30, p. 1.

Smith, Chris. 2005. “Carson Welcomes Home 2nd BCT.” Fort Carson Mountaineer, Vol. 63, No. 29 , p. 1.

Tonn, Rebecca E. 2006. “Hail and Farewell.” Fort Carson Mountaineer, Vol. 64, No. 42, p. 1. 
The $3^{\text {rd }}$ Armored Cavalry Regiment (3ACR), also known as the "Brave Rifles", was composed of approximately 5,200 soldiers at the outset of the Iraq War. From September 2001November 2001, the Tiger Squadron (with elements of the Longknife and Muleskinner Squadrons) participated in Operation Bright Star, a training exercise in Egypt. The 3ARC moved from Ft. Carson to Ft. Hood in July 2006 in accordance with the recommendations of the 2005 BRAC Commission. However, approximately 1,200 soldiers from the 3ACR remained at Ft. Carson and were assigned to the 2BCT 4ID when it arrived from Ft. Hood in June 2007. The regiment's aviation element also stayed at Ft. Carson, reflagged as $1^{\text {st }}$ Squadron, $6^{\text {th }}$ Cavalry (1-6 CAV).

Deployments to Iraq:

April 2003-April 2004 (25 fatalities)

February 2005-March 2006 (39 fatalities)

\section{Sources:}

Beebe, Dennis E. 2006. “Unfurling the Flag.” Fort Carson Mountaineer, Vol. 64, No. 27. p. 10.

Global Security. “Bright Star.” GlobalSecurity.org. Available at: http://www.globalsecurity.org/military/ops/brightstar.htm

Jewell, Lorie. 2004. “Across America, Soldiers Arrive Home to Rousing Welcomes.” Army News, April 16.

Available at://www.freerepublic.com/focus/f-news/1119221/posts

McRoberts, Shauna 2005. “3rd ACR Ready for Deployment.” Fort Carson Mountaineer, Vol. 63, No. 8, p. 1.

Rappold, Scott. 2007. “Fort Hood Brigade Says it’s Glad to be Back at Carson.” Colorado Springs Gazette, June 30. Available at: http://gazette.com/fort-hood-brigade-says-its-glad-to-be-back-at-carson/article/24272

Roeder, Tom. 2013. “Iraq: Ten Years Later.” Colorado Springs Gazette, March 15. Available at: http://gazette.com/iraq-ten-years-later/article/152318

Stein, Clint. 2006. “Warm Welcome Back.” Fort Carson Mountaineer, Vol. 64, No. 7, p. 9.

Third Cavalry Museum. 2008. “Blood and Steel!” Fort Hood, Texas 
Approximately 1,000 Special Forces soldiers belonging to the $2^{\text {nd }}$ Battalion of the $\mathbf{1 0}^{\text {th }}$ Special Forces Group (Airborne) and the $3^{\text {rd }}$ Battalion of the $10^{\text {th }}$ Special Forces Group (Airborne) were assigned to Ft. Carson at the outset of the Iraq War. Their repeated deployments to Iraq and Afghanistan were kept secret. The $3^{\text {rd }}$ Battalion of the $10^{\text {th }}$ Special Forces Group (Airborne), composed of approximately 400 soldiers, was activated at Fort Carson on August 19, 2010.

\section{Sources:}

Emert, Rick. 2010. “Special Forces Battalion Activates on Fort Carson.” Army.mil, August 30. Available at: http://www.army.mil/article/44463/

Roeder, Tom. 2004. “Special Forces Unit at Ft. Carson Secretly Deployed to Iraq.” Colorado Springs Gazette, December 6. Available at: http://www.ar15.com/archive/topic.html?b=1\&f=5\&t=302350 
When the 3ARC moved from Ft. Carson to Ft. Hood, the regiment's aviation element stayed at Ft. Carson, re-flagged as $\mathbf{1}^{\text {st }}$ Squadron, $\mathbf{6}^{\text {th }}$ Cavalry (1-6 CAV). The 1-6 CAV consisted of a headquarters troop, three air cavalry troops, an aviation support troop and a forward support troop (or approximately 380 soldiers). The 1-6 CAV moved to Ft. Riley in June 2009. The $1^{\text {st }}$ Battalion, $2^{\text {nd }}$ Aviation Regiment, $2^{\text {nd }}$ Infantry Division (1-2 AVN) was relocated to Ft. Carson from Camp Eagle, South Korea in April 2009. Composed of approximately 350 soldiers, 1-2 ANV was reflagged as the $1^{\text {st }}$ Battalion, 25 ${ }^{\text {th }}$ Aviation Regiment on April 16, 2013.

Deployments to Iraq:

August 2007-November 2008 (0 fatalities)

\section{Sources:}

Chapman, Jordan. 2009. “Combat Aviation Brigade Welcomes ‘Fighting Sixth’ from Fort Carson.” The $1^{\text {st }}$ Infantry Division Post, July 9. Available at: http://www.1divpost.com/newsdetail.asp?article_id=2776

Emert, Rick. 2009. “1-6th Cavalry Prepares for Move to Riley.” Army.mil, February 19, 2009. Available at: http://www.army.mil/article/17119/

Fisher, Devin. 2008. “1-6th CAV Home for Holidays.” Fort Carson Mountaineer Vol. 66, No. 48. p. 11.

Fisher, Devin. 2009. “Carson New Home to Apaches.” Fort Carson Mountaineer Vol. 67, No. 14. p. 1.

Rappold, Scott. 2007. “Fort Hood Brigade Says it’s Glad to be Back at Carson.” Colorado Springs Gazette, June 30. Available at: http://gazette.com/fort-hood-brigade-says-its-glad-to-be-back-at-carson/article/24272

Tonn, Rebecca E. 2007. “Carson Bids 1-6th CAV Farewell.” Fort Carson Mountaineer, Vol. 65, No. 34, p. 4.

Werthmann, Kelly. 2011. “Aviation Training Underway at Fort Carson.” Fox21News.com, August, 9. http://www.fox21news.com/news/story.aspx?id=649872

Zyla, Katherine. 2009. "News: 4th Squadron, 3rd Armored Cavalry Regiment Completes Iraq Tour.” dvidshub.net, January 22. Available at: http://www.dvidshub.net/news/29131/4th-squadron-3rd-armored-cavalry-regimentcompletes-iraq-tour\#.Ugq3UpHnbIU 